\title{
The Ambivalent Worker Max Weber, Critical Theory and the Antinomies of Authority
}

\author{
DAVID N. SMITH \\ University of Kansas
}

Social Thought \& Research, 1998, Vol. 21, No. 1-2

\begin{abstract}
It is seldom noticed that the concept of "the authoritarian personality" sprang from research -- above all by Max Weber and Erich Fromm -- on the ambivalence of the German working class. Unlike earlier social critics and theorists, Weber and Fromm did not simply assume that workers are naturally anti-authoritarian; nor, unlike many later theorists, did they assume the reverse. The working class, they found, is complex, divided -- indeed, contradictory. Some workers are anti-authoritarian, others worship authority, and many others have deeply mixed feelings. Hence the inadequacy of what Weber called "á priori class theories," which, without evidence, deduce consciousness from status, thus "finding" whatever they presuppose.

The alternative, a la Fromm's Critical Theory, is to probe not only the antipodes on the continuum from authoritarianism to anti-authoritarianism, but also the contradictory cases in between. Only in this way can the genuinely contradictory character of class feeling and thinking be understood.
\end{abstract}

At the start of this century, in the comparative innocence of the days when world wars, Bolshevism, and National Socialism were unknown, it was common to believe that the working class was antithetical to authority. For socialists, the working class was 
definable precisely by its lack of authority in production, ${ }^{2}$ and even non-socialists tended to accept the corollary assumption that workers were born rebels, naturally and irrevocably hostile to all the previously authoritative powers of Church, State, and country.

An influential statement of this outlook was given by the eminent German scholar Werner Sombart, for whom "the birth of the proletariat is tantamount to the annihilation of a thousand old relations... Ties of country, of village and family, of lordship and guild fall by the wayside. All authority relations slacken" (1906: 79). ${ }^{3}$ This typically modern social class, Sombart added, has a worldview as "uniform" as it is new, reflecting a "specifically proletarian psyche" (1906: 77, 78). Proletarians, that is, are anti-authoritarians.

Like most other social theorists in this period, Sombart believed that ambivalence was unique to the petty bourgeoisie. This middle class of shopkeepers, small farmers, clerks, and professionals was regarded as far from uniform in its worldview and deeds, susceptible now to radical iconoclasm, now to adulation of authority. Indeed, servile glorification of authority was viewed as distinctively petty bourgeois. Only this class, as the pre-eminent German Marxist Karl Kautsky wrote, "despairs...of securing a comfortable life for itself by its own doing"; only this class, squeezed between capital and labor, "clings to the power of the state, and even backs the violent

\footnotetext{
2 For present purposes the working class will be defined, a la Marx and Weber, as the class of formally free laborers who produce commodities for employers in exchange for wages; and "proletariat" and "working class" are used interchangeably, as synonyms. The latter usage is consistent, incidentally, with Marx's terminology, notwithstanding the widespread but mistaken belief with Marx defined "proletarians" as specifically industrial workers; in defines "industrial proletarians," like "agricultural proletarians," is fact, Marx larger class -- the proletariar per se - agricultural proletarians," as members of a sire of -- the proletariat per se - defined not by the technical character or relarions of production specifically capitalist socia relations of production berween employers and wage-earners.

${ }^{3}$ The working class is free, Sombart adds, "in the Faustian sense" - "free...from the shackles of all sentimentality, instinct, custom, beliefs and superstitions" (1906: 79). Sombart traces this freedom from authority this "specifically proletarian psyche," to an environment in which "all is uniform, monotonous," and monotony of experience leads to "monotony of perceptions" (1906: Unless otherwise noted, all translations are my own.
}

elements of militarism and the bureaucracy... ${ }^{4}$ Its ideal is a 'strong' man who will save it, and it runs after every adventurer who presents himself...as a strong man of that ilk" (1899, cited by Ayçoberry, 1981: 69).

This conviction, which imputes Bonapartist enthusiasm to "the middle classes" alone, was still conventional a generation later, even after the ascent of the curiously named "National Socialist German Workers' Party." Sociologist Theodor Geiger, for example, maintained that "the socially conscious worker who held down a job was infertile ground for the National Socialist seed," and that the Third Reich was, in fact, the product of "middle class panic" (1932, cited by Ayçoberry, 1981: 71; 1930, cited by Hamilton, 1982: 4). Even after Hitler fell, and after abundant contrary evidence accumulated (Rosenberg, 1934; Kele, 1972), this position remained widely popular (Lipset, 1959; Schweitzer, 1970; Mason [1977] 1993; Stachura, 1983) - so popular, in fact, that as recently as 1982 Richard Hamilton devoted a large book to refuting this thesis, which, he observed, is still widely accepted as "undisputed fact" (1982: 4; cf. Childers, 1983, Kater, 1983).

Still more recently a new and seemingly inadvertent variation on this theme has been advanced -- the claim (alternately Derridean, Foucauldian, and "functionalist") that Nazi racism sprang ultimately from "science," "bureaucracy," and "disciplinary society," hence from scientists, bureaucrats, and professionals. The working class, if not absolved of all guilt, normally flies far below the analytic radar screen in arguments of this kind (see below; and, for critical commentary, see Smith, 1996, 1995, 1994).

Meanwhile an equal and opposed view is also now common. This is the claim that German workers, far from resisting Hitlerism, were in fact Nazi authoritarians tout court. An early version of this outlook was put forward by Gerhard Ritter, who blamed German mass politics in general for Nazism (1948). Hannah Arendt followed with a blistering indictment of the

4 Note that the rubric "petty bourgeois" here refers both to the "old" petty bourgeoisie (farmers, shopkeepers) and to the purportedly "new" petty bourgeoisie of college-trained professionals and salaried bureaucrats. Though 1 dispute the validity of this class-analytic terminology (Smith, 1974), the essential point here is the "middleness" of these strata and their alleged exteriority to the proletariat. 
"mob" (1951), and, recently, Daniel Goldhagen stigmatized "ordinary Germans" of every class as cruel and willing Nazi-era executioners (1996; see Smith, 1998, 1996).

What unites these otherwise opposed claims is their monolithic nature. Rather than studying German workers empirically, they posit a metaphysic of class uniformity. Rather than seeing workers as individuals of varying and often competing impulses and loyalties, they generalize on á priori grounds about workers in the abstract. This is a reductio ad abstractum, parallel, in many ways, to the reduction of individuals to generic units of labor power in the market and workplace. Concretely, of course, workers are indelibly individual. But from the abstract perspective of the profit motive they are interchangeable, significant above all in monetary terms. The "worker," in other words, is an individual who is reduced, by stereotyped social practices, to an abstract class status. Yet even so workers remain ineradicably individual, with all the obdurate differences of personal character. As managers often learn to their woe, workers who are treated impersonally, as if they were walking ideal-types or engineers' sketches, tend to respond with defiance rather than compliance. Workers live a Janus-faced reality, which can only be truly appreciated in its duality.

Sociologists and historians often miss this point. Detlev Peukert, for example, invokes Max Weber to contend that Nazi racism was born of the scientific wish to rationalize the world. This, clearly, deflects attention away from the working class altogether ([1989] 1994: 279-286). Erich Goldhagen, meanwhile, faults Herbert Marcuse and others who view the world "through Marxian lenses" for allegedly failing to understand that, in Nazi Germany, "race consciousness eclipsed class consciousness," and that, in fact, the German working class was permeated by Nazi racism en bloc (1978: 8, 6, and passim; cf. 1979: 7ff).

The terms of this debate, as usual, are collective. Workers are alternately condemned or exonerated as a group, as if they were a solid crystal. This, of course, is nothing new. But there is a certain irony in the effort to claim Marcuse and Weber for views

\footnotetext{
${ }^{5}$ Erich Goldhagen originated the collective guilt thesis which, two decades later, his son Daniel made famous. Others accused by Erich Goldhagen of "Marxian" sins include Marcuse's fellow Frankfurt School theorist Franz Neumann and the martyred chronicler of the Warsaw Ghetto, Emmanuel Ringelblum.
}

of this kind, since they were, in fact, key figures in the intellectual tradition that most decisively broke with this abstract monism. Marcuse, in the very article that Goldhagen indicts (1934), sought to explore the inner logic of the authoritarian rule which, as Max Weber intuited and Marcuse's fellow critical theorists ultimately showed, attracts some workers while repelling others. The aim of their research, in fact, was to explain why workers differ. Why are some pliant, others deviant, and still others ambivalent? Why, in brief, is "class consciousness" contradictory?

\section{Beyond Traditional Theory}

The most influential answer to this question was formulated by thinkers associated with the "Frankfurt School" - the Institut für Sozialforschung - during its period of greatest creativity, from 1929 until about 1956. Alarmed and perplexed by the rise of fascist authoritarianism in Italy and Germany, the Institute's director, Max Horkheimer, worked out a comprehensive agenda for research into authoritarianism. The seminal result of this program -- The Authoritarian Personality (Adorno et al., 1950) is widely recognized as one of the founding documents of empirical social psychology. The earlier Institute studies, however, have remained surprisingly obscure - though they yield comparable enlightenment.

These studies -- a 1929-1931 survey of the Weimar proletariat, directed by Erich Fromm with help from Paul Lazarsfeld and Hilde Rigaudias-Weiss (Fromm [1939] 1984); a giant study of authority and the family in several cultures (Horkheimer et al., 1936); studies of the "authoritarian state" and propaganda by Horkheimer ([1942] 1973) and Leo Lowenthal and Norbert Guterman (1949); and many belletristic explorations of the "authoritarian worldview" as revealed in music and literature were carried out by a stellar group of writers and researchers, including Fromm, Lazarsfeld, Rigaudias-Weiss, Lowenthal, Herbert Marcuse, Karl Wittfogel, Friedrich Pollock, Franz Neumann, Ernest Manheim, Marie Jahoda, Ernst Schachtel, and many others.

The keystone of Horkheimer's early agenda was Studien über Autorität und Familie (1936), an epic exercise in theory and an ambitious survey of the literature on family discipline. Fromm, 
Marcuse, and Horkheimer contributed theoretical essays on the psychology, sociology, and history of authority, followed by a preview of the Weimar research (which went otherwise unreported until 1980) and a collection of essays on selected topics. ${ }^{6}$ The theoretical essays and the Weimar findings are especially important. ${ }^{7}$ Together with other articles from the same period - above all Horkheimer's "Egoism and Freedom Movements" ([1936b] 1993) - these essays pivot around two concepts that were, for the Frankfurt School, paired: the working class and authority.

Concern about proletarian feelings toward authority was, in fact, the central impetus that led Fromm, Horkheimer et al. into social psychology (cf. Bonss, 1984; Dubiel, 1985; Kellner \& Bronner, 1989). As it happens, a similar concern gave survey research its first fateful stimulus in the still-obscure efforts of the Verein für Sozialpolitik, whose leading figure, Max Weber, played a major role in the early application of empirical methods to class analysis (Bernart, 1986; Käsler, 1988) - and whose example was not lost on the early Frankfurt School, though few later social researchers seem to have noticed it. "One has the impression," Lazarsfeld dryly remarks (1965: v), "that Max Weber wrote only on the Protestant ethic and ideal types. It reminds one of the facetious remark that Beethoven wrote only three symphonies -- the 1st, the 5th, and the 9th."

\footnotetext{
6 Autoritat und Familie has received remarkably little attention. Few historians devote more than a few lines to it; see, e.g., Zoltan Tar (1977) and David Held (1980). The honorable exceptions to this rule -- most notably Martin Jay (1973), Rolf Wiggershaus (1994), Rainer Funk (1982), and Helmur Dubiel (1985) - are, somewhat less cursory. The obscurity proletariat (11939] 1984) is more undersing unknown until it languan language text, originally intended for publication by Columbia University Press

${ }^{7}$ Two of these essays are available in English: "Authority and the Family" (in Horkheimer, 1972b) and "A Study on Authority" (in Marcuse, 1983). Fromm's essay (1936a), meanwhile, will ap pear shortly in a translation by George

${ }^{8}$ Other major contributions from this period include Fromm (1937) and an essay by Marcuse ([1937] 1988), an essay "prompted by Max Horkheimer's remarks about 'affirmative culture' and the 'false idealism' of modern culture" (Marcuse, [1937] 1988: 277; the reference is to remarks in Horkheimer, [1936b] 1982-83).
}

The reality, however, is that Weber was deeply committed to empirical class analysis. Along with six major studies of his own -- studies that yielded "at least 1000 pages of research ... which, in style and format, would not be easily distinguished from the pages of our contemporary sociological journals" (Lazarsfeld. 1965: vi) - Weber supported many projects by associates and students, ranging from rural labor surveys to a study of peasant radicalism by a student in one of his final seminars (Weber, 1899; Matte, 1921). Many of these studies were significant in their own right, and several exerted considerable influence on on later research as well.

In what follows I trace the line of influence leading, from the earliest survey research, through Weber's efforts, to the early Frankfurt School. The connecting thread is shared concern about the political valence of that fateful force, the modern working class.

\section{The Working Class and Empirical Sociology}

It was in the aftermath of the French revolution of July, 1830, that the terms "socialism," "communism," and "proletariat" entered the European political vocabulary. "Socialism" was first used with a political meaning by French workers in 1831-32; it entered colloquial English shortly after (Fetscher, 1972). The word "communism" was introduced slightly later, by Étienne Cabet in his utopian novel, Voyage en Icarie (1840), and soon acquired a considerable vogue. As early as 1846, in fact, in the Staatslexikon of Rotteck \& Welcker, Kommunismus earned the distinction of being called a spectre - a phrase immortalized shortly after by Marx \& Engels ([1848] 1994: 105):

A spectre is haunting Europe -- the spectre of communism. All the powers of old Europe have entered into a holy alliance in order to lay this spectre: Pope and Tsar; Metternich and Guizot; French radicals and German police.

In 1848 this spectre materialized in the form of a militant proletariat - with objectives of its own and the will to pursue them. Neither socialism or communism is fully intelligible without the corollary idea of working-class radicalism, which first gained widespread currency in the social and industrial conflicts of the 1830's. It was at this point (Foster, 1974: 42) "that for the first time wage-earners were seen as the potentially 
revolutionary class." The likely social content of this class potential was indicated by the Poor Man's Guardian in 1833 when it spoke of a working class that wished for "an entire change in society - a change amounting to a complete subversion of the existing world" (cited in Briggs, 1972: 409). This vision of a subversive class was theorized by Lorenz von Stein (1842), who concluded that "antagonism against property..becomes rooted in the industrial proletariat," once workers see that capitalist interests differ "fundamentally" from their own (cited in Kernig, 1972: 59-60; cf. Briefs, 1937: 69-74). ${ }^{9}$

It was from Stein, among others, that Karl Marx drew his initial inspiration.

It was in this period, too, that interest in the proletariat inspired the first major wave of empirical survey research, which took the form of a series of major enquêtes ouvrières conducted in France from $1830-48$ by philanthropically minded private reformers (Rigaudias-Weiss, 1936a). Not long afterwards, in the wake of the 1848 revolution, the French state sponsored a series of further studies emulated, in 1875 and after, by Bismarck's Germany. A different research model was adopted in England - that of the traveling factory inspectors, praised by Marx in Capital.

As Oberschall notes, the raison d'etre for this first wave of empirical studies was to ascertain "the material and moral condition of the working classes..." (1965: 3). According to Rigaudias-Weiss (1936b: 97), most early studies were "conducted essentially from viewpoints of social legislation [and] philanthropy," but some were, in unremarkable ways, "animated by a bias against the labor movement."

Whether hostile or sympathetic, though, the early survey researchers were preoccupied by "the social question," i.e., labor and class conflict. This is not to say, however, that the net results of these early surveys were very appreciable. On the contrary, as a German editor wrote in 1891, "We [are] better acquainted with the conditions of life of the half savage African tribes than with those of our own peple" (cited in Oberschall, 1965: 81, from Popp, 1912). Hitherto only a few minor studies had been scientifically conducted. The ethnological pioneer Wilhelm

\footnotetext{
9 Throughout this article I will use the terms "proletariat" and "working class" interchangeably. My reasons for doing so are explained in Smith $(1974,1983)$.
}

Mannhardt, for example, had circulated a questionnaire in 1865 asking peasants various questions, including, e.g., whether "you have in your district tales about flying dragons, dwarfs, cobolds [and] witches who steal the grain from the peasant's field to take it to others through the air?" (Oberschall, 1965: 64, citing Mannhardt, 1865). In 1866, Karl Marx circulated a small questionnaire on peasant issues at a congress of the International Workingman's Association. Fourteen years later, at the request of the Parti Ouvrier Franÿais, Marx drafted a large "Workers' Questionnaire" as well ([1880] 1989). Published in La Revue Socialiste in the format of an enquête outrière, Marx's survey posed 100 brief questions - some of considerable interest. The most notable feature of this enquete was that it "tried to clarify...the thoughts of the workers themselves on their...situation and its... causes" (Rigaudias-Weiss, 1936b: 97; cf. Rubel, 1957: 416f.). ${ }^{10}$

Though modest, Marx's survey was advanced for its time. Just three years had elapsed since the first major German social science association (the Verein für Sozialpolitik, founded in 1872), had conducted its first small study, and the labor movement generated few similar studies. " Indeed, from this point on, "an interest in the proletariat as an object of empirical enquiry emerged entirely from outside the labor movement" (Bonss, 1974: 10).

\section{Max Weber and the Verein}

In the closing decades of the nineteenth century, the Verein für Sozialpolitik became the leading force in survey research,

\footnotetext{
10 In the words of the preamble to this questionnaire, "We hope to find support for our cause among all the urban and agricultural workers, who understand that they alone can describe the hardships they endure with the full knowledge of the matter; that they alone, and not the saviors sent by Providence. can vigorously apply remedies in the struggle against social evils from which they suffer..." (1880] 1989: 636 n. 375).

11 Marx's questionnaire, besides appearing in La Revue socialiste (No. 4, April 20, 1880) was "reprinted in quantity for distribution throughout France," as Marx 1880) was "reprinted in quan 1989: 43). Yet I have found no evidence that the subsequently reported ([1880] 1989: 43). Yet 1 have found were ever tabulated, either in this conn translations which appeared later in 1880 in Italian, Polish, and Dutch socialist newspapers.
} 
performing a series of studies focused primarily on the working class: in rural areas; in cottage industries; in trade and transport; etc. An early Verein member, Gottlieb Schnapper-Arndt, conducted a pioneering field investigation of cottage industry in five villages, which he explained by saying (1881) that "reports on the condition of the people in the cottage industries, especially by $K$. Marx, [had] awakened in me the desire to see the truth for myself" (cited by Oberschall, 1965: 71). SchnapperArndt also assisted with the first Verein survey of rural labor and wrote an analysis of survey methodology (1888) which remained the only document of its kind until Max Weber, much later on, became concerned with methodology in empirical research" (Oberschall, 1965: 24).

In September, 1890, the Verein authorized three senior members to plan and guide an ambitious survey of German rural workers. Questionnaires were sent to 3,180 rural employers in every corner of Germany, of whom 2,277 responded. The aim of this survey was explained in the cover letter: "Of all the questions facing farmers at the moment," the Verein researchers wrote, "it is the question of the workers which heads the list..."

In order to be able to rectify the existing damage in the whole worker relationship...the first precondition is a clear and reliable presentation of the actual conditions' (cited in Käsler, 1988: 52).

A second and larger survey form was sent to 562 selected informants, of whom 291 responded. Max Weber, who had recently joined the Verein, wrote a massive monograph on the east German findings, "The Situation of Rural Workers in Germany East of the Elbe River" (Weber, [1892] 1984a \& 1984b; cf. Bernart, 1986; Riesebrodt, 1984; Tribe, 1983; Munters, 1972; Honigsheim 1946, 1949). With economic analysis and sharp political argument as his point and counterpoint, Weber probed the likely political repercussions of seasonal immigration by Polish fieldworkers into Prussia, Silesia, and elsewhere in east Germany. His main concern, he said, was to find a way to reconstruct, on a bourgeois foundation, the dissolving community of interests that had formerly bound the different strata of rural workers to their masters.

At this point, Weber was still susceptible to the notion of proletarian uniformity, writing that "the one-time farmer [who becomes] a proletarian...becomes a member of the great uniform mass of the propertyless" and ceases to feel a patriarchal tie to the master (1892, in Käsler, 1988: 58). Now "his material interests...run counter to those of the employer, [and] predispose him to...the class consciousness of the modern urban and rural proletariat" (1892, in Käsler, 1988: 56). Hoping to elevate rural German workers above the mass uniformity of the workers "to the status...of peasant farmers," spiritually and materially allied with estate owners, Weber urged a policy of "internal colonization" in which rural workers would become small landowners, while Russian and Polish migrant workers were kept out of Germany. "I regard the 'question of rural workers" quite exclusively from the standpoint of Staatsraison," Weber said bluntly. The key question from this standpoint is how to strengthen Germany, not, he stressed, "are [the peasants] having a good time or a bad time, how can they be helped?" (1892, in Käsler, 1988: 60) ${ }^{12}$

This strategy alone, however, would not be enough to calm the rural class struggle, Weber believed, since the "relation of domination over...the free contractual laborer" has a subjective side as well (1892, in Käsler, 1988: 55). It was on this ground that Weber dissented from the Verein's mainly structural orientation. It is less useful, he wrote, to know "how high the workers" earnings actually [are] than to know whether they [are] satisfied..." (1892, in Bonss, 1984: 11; Oberschall, 1965: 27; italics mine). Weber thus decided to conduct another study with greater stress on social psychology.

Under the aegis of the Evangelical-Social Congress, and in partnership with its Secretary, Paul Göhre - whose popular book Three Months in a Workshop ([1891] 1895) had just appeared - Weber sent questionnaires to 15,000 ministers, who were asked to query rural workers directly. Weber chose ministers as informants rather than estate owners because he felt that the authoritarian complacency of the noble would preclude

12 Käsler argues convincingly (1988: 55) that the "results of this 891-page investigation became a leitmotif through Weber's work, making the knowledge of the reits undeniably imporant for a comprehensive understanding of his work. Neither his inaugural lecture in Freiburg in 1895" - probably Weber's single most defining political statement (see Eden, 1983) -- "nor his lecture on the occasion of the World Exhibition in St. Louis in 1904 can be understood without a knowledge of the enquiries." Furthermore, "the enquiry was a decisive step for the development of a specific methodology in the empirical social sciences in Germany - a fact which until today has hardly ever been taken into consideration." 
insightful inquiry. ${ }^{13}$ "This landed nobleman," he wrote scornfully, "possessed the naive conviction that Providence had arranged things in such a way that he was called to dominate and the 'Others' were called to obey. Why? He does not think about such things. The absence of reflection was of course one of his most essential virtues of domination" (Weber, 1894: 70, in Käsler, 1988: 62).

Weber's results in this study were inconclusive, but he still felt certain that he was on the right track: "...all surveys up to now," he wrote in his final report, "have shown with a high probability that the problems presented by the conditions of rural labor are principally of a psychological nature" (1893: 535, in Oberschall, 1965: 30),

Subsequently, especially after writing The Protestant Ethic and the Spirit of Capitalism (1904-05), Weber continued to play a key role in German research on working class psychology. ${ }^{14}$ In this phase, as before, "most empirical work was...concerned with but one topic: the working classes. The two areas of major concern were the problem of work in the broadest sense, and the social psychology of the proletariat" (Oberschall, 1965: 76).

\section{The Proletarian Personality}

Weber played a major role in each sphere. Near the turn of the century he assisted Walter Abelsdorff with a study of German printers. This was a large study, probing the views of nearly onesixth of all German printers and compositors, but, for Weber, it was just a "trial beginning" (1900: viii, in Käsler, 1988: 67). More ambitious surveys of the same kind were pursued in the years 1908-12, when Weber plunged deeply into social inquiry in connection with the two most far-reaching studies of the preWorld War 1 era - a massive Verein study, The Selection and Adaptation of Workers in Heavy Industry (Alfred Weber et al.,

13 Weber's opinion was that "the clergyman regards...the agricultural worker from a point of view quite different from that of the employer. The latter is biased, like the worker himself..." (1892, in Käsler, 1988: 61).

${ }^{1+}$ Indeed, although valuable work was done by many others as well (including Rade [1898] and Piechowski [1927]), Lazarsfeld and Oberschall feel that Weber's role was so pivotal that early social research in German can be divided into two eras -- before and after Max Weber (1965).
1909-1911), and a major social psychological study of The Working-Class Question by Adolf Levenstein (1912).

Both of these studies expressly focused on the "spiritual life" (Seelenleben) of the German working class. Yet oddly enough several recent historians have alleged that Weber's interest in this research pivoted mainly around non-psychological questions. ${ }^{15}$ The truth, in fact, is exactly the reverse.

The study of heavy industry - initially proposed by Weber's brother, Alfred, at the Verein conference in 1907 - was the most elaborate yet conceived. It was the first Verein survey to query workers directly, and it was also the first to use multivariate statistics. No fewer than six volumes of results were published between 1910 and 1915 on a range of industries - textiles, automobiles, electrical power, engineering, printing, stoneware, leatherware, and others (see Campbell, 1989: 87-91; Raehlmann, 1988: 78-87; Gorges, 1980: 477f.; Boese, 1939: 147f.; Herkner, 1912: 117f.).

Max Weber spent well over a year planning this project. In a four-part series of Archiv für Sozialwissenschaft und Sozialpolitik articles -- a lengthy "Methodological Introduction" (1908) and a three-part monograph on the psychophysics of industrial labor (1908-09), all four parts of which were later reprinted in his Gesammelte Aufsätze zur Soziologie Aufsätze und Sozialpolitik (Weber, [1908-09] 1924; also [1908-09] 1993) -- Weber reviewed the research literature, reported on his observations in the summer of 1908 while "plunged deeply in the account books and production registers" in a weaving mill in Oerlinghausen owned by relatives (Marianne Weber, [1926] 1975: 345), and formulated a

15 Anson Rabinbach (1992: 9, 189f.) even goes so far as to accuse Weber of defining labor "in largely energeticist terms," without showing due concern for working classs culture and psychology. A more qualified but essentially similar position is taken by Eberhard Demm (1987: 92) and Gert Schmidt (1976: 63), both of whom concede that Weber declares social psychology to be a central focus of the research mission of the Verein studies, but then say that this was not truly characteristic of Weber's views. These extraordinary claims are very far from the mark, as I show not only below (briefly) but also in a forthcoming paper, "Promethean Slavery: Alienated Labor and the Brothers Weber." Rabinach is led astray by his wish to portray social science (one-sidedly) as almost uniformly mechanicist in the post- 1890 period; Demm wants to credit almost uniformly mechan period; Demm wants to credit Alfred Weber for the psychological orientation of the Verein studies; and Schmidt is hostile to the Lazarsfeld/Oberschall/Schad reading of Weber's industrial sociology, which he calls the "American" interpretation. Rabinbach and
Schmidt, in particular, are very weak on the facts. 
set of prototype questions that later guided the Verein investigators.

In this research Weber stressed the significance of learning "the effects of heavy industry upon the individual" in terms of "the physical and psychic qualities it promotes" ([1908] 1924: 1). To analyze the physical side of factory labor, Weber applied the "psychophysics" of his Heidelberg colleague Emil Kräpelin, focusing on "the power-economy of the nervous system and the muscles" ([1908-09] 1924: 111), with emphasis on "stimulability," "fatiguability," and "distractability" of what one earlier writer had called la machine humaine (Querton, 1905, cited by Weber [1908-1909] 1924: 253, n. 2). Weber's principal finding was that as the week elapsed, productivity rose swiftly from Monday to Wednesday, fell on Thursday, and rose again slowly on Friday and Saturday ([1908-1909] 1978: 370; Oberschall, 1965: 119).

In his psychophysical research Weber's goals were practical and bourgeois. On the one hand, he made no bones about the fact that issues treated "in the present survey" are examined "entirely from the point of view of profitability" ([1908-09] 1978: 371). Psychophysical changes in the labor process, he belived, could plainly augment profits. As an illustration, he cited Abbe's experiment at the Zeiss optical works, "where," Abbe noted, "the working day was reduced and production was slightly increased just in such an automatic unconscious way, independent of the good will or ill will of the workers" (1906, in Oberschall, 1965: 117-118). Even further, in neo-Taylorist terms, Weber argued that psychophysics was uniquely suited for inquiry into factory work, since in a strictly hierarchical system of this kind the control system "reaches down to the simplest hand movement of the worker" (1908: 59-60; cf. Oberschall, 1965: 122). ${ }^{16}$

Still, Weber agreed that many vital questions are unanswerable in purely physical terms -- and indeed the Verein studies were explicitly intended to correct and complete the psychophysical picture by introducing social psychological concerns. It is crucial, as Weber wrote, "to consider the feelings and subjective attitudes of the workers themselves" -- that is, the "differences in their 'characters' and in their 'intellectual' and 'ethical' attitudes..." ([1908-09] 1978: 371, 373). This, in turn, requires a v'erstehenden awareness of worldviews and values, with a dual

\footnotetext{
${ }^{16}$ For data on psychophysics see Campbell (1989) and Geuter (1993).
}

focus not only on utility-maximizing behavior but on ethicallymotivated conduct as well ([1908-09] 1978: 372). Weber notes, for example, that productivity rises to unusual heights among young women from Pietistic families, who shun dance halls and other amusements. This, he says, shows the persisting influence of Protestant asceticism, with its attendant sense of an "inner relation to 'God-willed' vocations" (Weber, [1908-09] 1924: 161). Elsewhere, Weber discusses other aspects of "worker 'psychology' in the practical-ethical and worldview-laden sense of the word" - individualism, patriarchy, and the "politicalsocial" worldviews and conventions of radical, religious, and Social Democratic workers ([1908-09] 1924: 160, 162; cf. 161, 163 , 239-40, \& 254; and cf. Hennis, 1988, concerning Weber's conception of personality). ${ }^{17}$

\section{Class and Character}

Survey research, for Weber, could be an invaluable supplement to the interpretive study of economic ethics, and it is hardly accidental that his major surveys were conceived during his years of greatest productivity. Starting with the publication of his two great essays on the spirit of capitalism (Weber, 1904-05. [1906] 1946), Weber had entered a 15-year phase of prodigious activity. His effort to link Calvinism and capitalism soon evolved into a many-sided effort to connect ethics and economics on a world scale. By 1917, Weber had finished seminal studies of the religions of China and India ([1916] 1964 and [1916-17] 1967), asking, in brief, why Puritanism and the capitalist spirit arose first in the Occident. His great systematic work Economy and Society ([1922] 1978) was underway by 1913. Though this work was never finished - delayed by the "thunderclap" of World War I, Weber's return to academia, his rising political profile, and the

17 Weber's protégée, Marie Bernays, added a sociologically relevant insight very close in spirit to the concerns outlined argued by Alfred and Max Weber in 1909 (in the "Debatte" sections of the Schriften, Bd. 132, pp. 238ff.) - when she noted that the "separation of great masses of workers in a factory into individual small groups plays a role for the psyche of the worker that should not be underestimated: I would suggest that it saves him from sinking into the mass, from becoming a mere number, inasmuch as there exists a small circle to which he can belong and in which he can achieve some recognition" (Bemays, 1911. cited in Oberschall, 1965: 129). Bernays, who had spent four months working incognito in a textile factory, is rightly credited by Oberschall with anticipatin the results of Elton Mayo's Western Electric experiments 20 years later. 
demands of Ancient Judaism ([1917-18] 1952) and the revised Protestant Ethic ([1920] 1958) - Economy and Society is still testament to Weber's unity of vision and capacity for synthesis. Only Ancient Judaism, in my opinion, is equally profound in its analysis of the ethical pre-requisites for capitalism. Here, as elsewhere, Weber emphasized the cultural and psychic ties which bind societies, alternately, to tradition and revolution.

Weber's surveys dovetailed closely with this historical research. Started just three years after the publication of his initial essays, and finished the year before he began Economy and Society, Weber's surveys were an integral part of his theoretical agenda. An indication of what might have come next -- if the war, academic disfavor, and Weber's early death had not intervened can be glimpsed in the second of the two major studies to which Weber contributed, Adolf Levenstein's Die Arbeiterfrage (1912). Levenstein, reputedly an anarchist, who "had himself been pushed around in a proletarian...existence" (Weber, 1909: 952, in Bonss, 1984: 13), first queried his fellow workers in 1905 in a never-published effort to see what they thought about the idea of a general strike. Not long afterwards, Levenstein decided to pursue research to find out if "the routinization and monotony of industrial work systematically increased the spiritual poverty of the proletariat" (Bonss, 1984: 13). Influenced by Weber's methodological essay, Levenstein decided to test this hypothesis with a 26-item questionnaire, which he circulated to miners, steelworkers, and textile workers. With help from his friends, Levenstein succeeded in collecting 5,000 completed questionnaires - no less than 62 percent of the total he had distributed! ${ }^{18}$

After showing his data to Weber, though, Levenstein made no immediate effort to tabulate or publish it, instead editing anthologies (1909a, 1909b) of letters, poems, and reflections sent to him by some of his respondents. Perturbed by Levenstein's relative inactivity, Weber went so far as to publish a letter urging him to analyze his data - advice Levenstein ultimately accepted.

\footnotetext{
${ }^{18}$ This excellent research result was achieved despite opposition from the Social Democratic Party (SPD), which, through its organ Die Neut Zeit urged wocial not to return Levenstein's questionnaires. The SPD eviden Zeil, urged workers as a politically unreliable interloper; see Kem (1982: 107, and cf. Roiser \& Willig 1995: 88, 93, who mistakenly say that Levenstein was colla and ct. Roiser \& Willig, they may have been misled by the fact hat questionnaires to SPD members).
}

"The first great attitude survey thus was not lost to science" (Oberschall, 1965: 142).

Levenstein's style was endearingly naive ("Write from the bottom of your soul," he urged his respondents) but it was also fruitful, yielding results of great interest. To start with, Levenstein established that German industrial workers were overwhelmingly socialist-minded, and that few were religious in any traditional sense. "The Social Democrats had by this time achieved a monopoly of communication with the workers. Over 40 percent of the textile and steelworkers reported reading primarily socialist books and trade union literature... There existed no serious competition for the political allegiance of the workers on the part of any alternative ideology" ([1908-09] 1924: 163). Only 25 percent of the workers reported a belief in God.

For German workers, in other words, the ideas of the ruling class had seemingly ceased to be the ruling ideas. Neither Junker reaction nor imperial "liberalism" could claim hegemony over the proletariat. Workers had apparently renounced Lutheran as well as Catholic piety - opting, instead, for "the thought-world of socialism" ([1908-09] 1924: 163). The fears that had led Bismarck to outlaw the Social Democratic Party (SPD) seemed fully justified.

But Levenstein also showed that German socialism was far from subversive. The famous "revisionism" of Auer, Bernstein and other SPD leaders rested on the firm foundation of a widespread popular gradualism. Aside from a nucleus of revolutionaries and a stratum sunk in apathy, the German working class consisted of cautious pragmatists. Few workers were happy with prevailing wages and conditions, but fewer still were open to insurrectionary solutions. Weber had been right, in other words, when he had "...advised the German princes, if they wished to appease their terrors of socialism, to spend a day on the platform at a socialist congress, so that they might convince themselves that in the whole crowd of assembled revolutionists '...the dominant type of expression was that of the petty bourgeois, of the self-satisfied innkeeper,' and that there was no trace of genuine revolutionary enthusiasm" (cited by Michels [1915: 283] from a stenographic report of Weber's October 2 speech at the 1907 Magdeburg Congress of the 
Verein). ${ }^{19}$ Later, upon reviewing Levenstein's data, Weber wrote that "this...confirms at least for me...that the manner of perception of the proletarian...is far more similar to that of the "bourgeois' than the á priori class theorists think" (1909: 956, cited in Oberschall, 1965: 106).

At this point Levenstein took an important methodological step, elaborating a rough scheme of proletarian character types. Four mentalities, he said, were typical among German workers: the "intellectual, contemplative, pretentious, and mass." As a radical, Levenstein sympathized with the intellectual stratum -- the cream of the proletariat, "youthful" in its optimism and made up of "creative, autonomous individuals." But Levenstein was realistic enough to see that 'autonomous individuals' were a small minority among German workers (forming less than 6 percent of his sample). Nearly two-thirds fell into the 'mass' category (which he uncharitably called the 'spiritually dead'), while the remainder gave 'pretentious' or 'contemplative' answers.

This proletariat was far from revolutionary, despite its 'class consciousness.' In this respect, Levenstein anticipated the conclusions Michels would reach in his famous analysis of the 'oligarchic trend' in the Social Democratic Party. ${ }^{20}$

Although Weber criticized Levenstein's methods, he agreed (1909: 956) that it is both possible and enlightening to conceive "foundation types of proletarian mentality and awareness." This seems to have been the message, as well, of a study by the exiled Russian revolutionary socialist, Eugen Leviné, Types and Stages in

\footnotetext{
${ }^{19}$ Weber

Weber repeated this sentiment in "Politics as a Vocation," stating that, after the SDP's visionary leader August Bebel died, "Trade-union officials, party
secretaries, and journalists came to the top. The instincts of officialdom dominated the party - a highly respectable officialde instincts of officialdom ([1919] 1946: 112). the Workers Opposition in the Bolsheviked by Alexandra Kollontai, leader of passivity of the proletariat at this critical Party after the revolution: "The know the German workers' at this critical moment can surprise only those who know the German workers' movement from the imposing figures of its annual reports, its 'workers palaces' and its growing number of representatives in local government and in parliament. For those who were familiar with the everyday life of the German movement the silence and passivity of the broad masses does not come as a surprise" (1915] 1977: 99-100).

Michels does not cite Levenstein, though he had probably heard of Die Arbeiterfrage from Weber, to whom he dedicated Political Parties. Kelly (1987: 10) calls Levenstein's book "one of the pioneering works of modern sociological
}

the Development of Trade Union Workers (1913). ${ }^{21}$ Leviné, who studied with Weber's successor at the University of Heidelberg. Eberhard Gothein, believed that he "...could serve [the workers] best if he understood their mentality, their strengths and their limitations" (Leviné-Meyer, 1973: 15-16). ${ }^{22}$ To achieve this, he circulated questionnaires among 1,500 industrial workers in the city of Mannheim and worked as a laborer in two Mannheim factories. With 500 completed questionnaires in hand, Leviné wrote up his results in the form of a dissertation. Although the University of Heidelberg reports (in a private communication) that this dissertation seems to have been lost, Leviné's widow, Rosa Leviné-Meyer, notes (1973: 16) that, after writing it, Leviné "no longer idealized 'the people.' He saw in them the powerful force...destined to transform the hated social order, but he was not blind to their shortcomings, suburban outlook and indolence."

Weber et al. were prevented from pursuing this line of research by the outbreak of the World War. At the same time, though, it should also be noted (Lazarsfeld, 1965: vi) that Weber's empirical efforts "were not accepted as a legitimate part of sociology by the German universities." Though most of his six surveys were praised individually -- the psychologist Hugo Münsterberg (1913: 149), for example, lauded Weber as a "brilliant political economist" who had "thoroughly discussed" and "explained...certain industrial facts" -- his overall survey research project was received somewhat coldly. Frustrated by the halfhearted support of his Verein colleagues, Weber helped to start the German Sociological Society in 1910 in order to better promote "scientific investigations and surveys" (in the language of the Society's charter). A scant two years later, however, Weber concluded that the Sociological Society was also insufficiently empirical and ceased to play a part in it.

Weber was also keenly aware of the difficulty of securing clear results with the limited methods of his day. After hearing several

\footnotetext{
2l The only data on this study comes from Leviné-Meyer (1973); it is not cited by Lazarsfeld, Oberschall, or Bonss.

2 Gothein was himself a quasi-socialist, the author of a study of the industrial reserve army and other now-forgotten works. Levine carried out this research under Alfred Weber (whose recommendation, in fact, won him admission to the
} German SPD). 
Verein luminaries praise the study of heavy industry, for example, Weber (1912: 190-1) rose to express a cautionary view: "No definite results have so far been accomplished, nothing more than a few numbers to support a few hypotheses..." Data analysis might well "yield valuable and definitive results" at some point, but, for the moment, it was entirely premature to speak of "magnificent studies" and "great 'findings'..."

After the war, Weber encouraged Wilhelm Matte, a student in his Munich seminar, to conduct "probably the first field study of political organizations" -- a study probing "the extent and nature of peasant support for the [left-radical] Eisner government and its Workers' Councils during the brief postwar socialist tenure of power in Bavaria" (Oberschall, 1965: 75; cf. Matte, 1921). Weber also lectured and wrote at length on the Bavarian commune, the Bolshevik revolution, and issues of working-class politics. He inquired, for example, into the character of revolutionary motives. "The real empirical sociological investigation," he wrote, "begins with the question: What motives determine and lead the individual members and participants in this socialistic community to behave in such a way that the community [comes] into being in the first place and that it continues to exist?" ([1922]
1978: 18)

Weber strongly doubted that the European revolutions of his time would lead to permanent changes in the political and social status of the proletariat. If capitalists were banned from the economy, he asked, "who would take over and control this new economy"? ([1918] 1967: 35) Not the proletariat, he argued. When the dust settled, the workers, in all likelihood, would still be disenfranchised. "For the time being, at any rate, it is the dictatorship of the officials which is on the march and not that of the workers" ([1918] 1967: 30). This prophecy would have seemed much less plausible just a few years earlier. What had changed?

\section{An Inverted World}

The promise of civilization darkened radically with the outbreak of World War I. Until then it had seemed likely that the dreams of the Enlightenment would be realized in the twentieth century. Humanitarian goals - including, for workers, the victory of "social democracy" over authoritarian class rule - were to be accomplished by gradual steps in every sphere. Superstition would be routed; the irrationality of the social system would be overcome; the atavisms of "prehistory" would disappear: injustice, war, class divisions. Enlightened reason would triumph, not just in physics but in politics, as the ineluctable result of an evolutionary process ruling both societies and species. Only in the treatises of ethnographers would reminders of the savage past remain.

So it was thought.

Upon the fatal outbreak of 'the Great War' this vision was dealt a stunning blow. It soon became clear, in the killing fields of Belgium and Holland, that the bestialities of war, far from being abolished, were being mechanized. The grim reaper had given way to a threshing machine. Whole nations were now 'exposed to the risks of battle, in a war in which all of Europe was caught in the crossfire. The supreme rationality of modern science - in the era of Nobel, Cavendish, and Curie - had been manacled to the service of a profound irrationality.

For left-wing radicals the war was especially traumatic. Prior to the war the 'orthodox' view had been that the solidarity of workers would either ensure peace or, if war broke out, lead to a revolution. Eduard David, the leader of the socialists in the German Reichstag, had expressed a typical view in 1912 when he said that the era of automatic obedience had come to an end. "Hitherto, the masses have always blindly let themselves be driven against one another to mass murder by those who had an interest in war. That has stopped. The masses have ceased to be the instruments and footmen of war profiteers" (cited in Luxemburg [1916] 1971: 332). Just a week before the outbreak of hostilities, the German Social Democrats spoke eloquently of their antiwar intent: "We are no marionettes. We fight with all our might against a system that makes men the powerless tools of blind circumstance, against this capitalism that is preparing to change Europe, thirsty for peace, into a smoking slaughterhouse" (cited in Luxemburg [1916] 1971: 332).

The war made a mockery of this fine sentiment. Socialist workers in France, Germany, and elsewhere rallied to the defense of 'the Fatherland,' cheered on by their leaders. All Social Democrats in the German Reichstag except Karl Liebknecht voted in favor of war credits. Comparable turnarounds occurred elsewhere, as working class solidarity fell 
victim to narrow nationalism. No fewer than 1.5 million people died in France alone, and, on the margins of the conflict, an unprecedented eruption of genocide led to the deaths of at least 800,000 Armenians.

Many radicals were shocked and dispirited. V. I. Lenin suffered a nervous breakdown, and Rosa Luxemburg was inspired to declaim, with bitter irony: "Workers of the world, slit each other's throats! Now millions of workers of all lands are falling on the field of shame...the slave-song on their lips" ([1916] 1971: 335). With the lightning of war there came "enlightenment," too. A harrowing new image of the future was thrown into bold relief. It appeared, now, that a double spectre haunted Europe: not just communism, but the prospective failure of communism.

As Luxemburg wrote in a wartime pamphlet, a stark choice had been posed: "Either the triumph of imperialism and the destruction of all culture (and, as in ancient Rome, depopulation, desolation, degeneration, a vast cemetery), or the victory of socialism, i.e., the conscious struggle of the international proletariat" ([1916] 1971: 334). ${ }^{23}$ She stressed the "terrible seriousness" of the altemative posed decades earlier by Friedrich Engels - "either an advance to socialism or a reversion to barbarism" (cited in Luxemburg, [1916] 1971: 334).

This stress here on "the conscious struggle" of the proletariat is notable because Luxemburg had been the leading standard bearer of the view that capitalism is inevitably destined to fall under its own weight. Capitalist collapse might not be imminent, she had said, since capitalism still had a world to conquer. ${ }^{24}$ But Luxemburg foresaw bitter travails for capital as it expanded. With a bleakness of vision reminiscent of Hieronymous Bosch, Luxemburg depicted a path to collapse strewn with the debris and detritus of a system fueled by class and national antagonisms. "The more capitalist countries participate in this hunt for accumulation areas, the rarer the noncapitalist places still open to the expansion of capital become

23 Emphasis mine. I've slightly modified the translation.

24 "After many centuries of development, the capitalist mode of production still constitutes only a fragment of total world production. Even in the small continent of Europe, where it now chiefly prevails, it has not succeeded in dominating entire branches of production, such as peasant agriculture..." (Luxemburg, [1913] 1951: 358). and the tougher the competition; its raids turn into a chain of economic and political catastrophes: world crises, wars, revolution" ([1921] 1972: 60).

Prior to World War I, Luxemburg had often argued in objectivist terms that revolution will inevitably break the chain of wars and disasters - that, on the eve of barbarism, the working class will finally triumph. Though accumulation leads "logically" to collapse, Luxemburg stressed that there is "as little chance of this conclusion being reached as there was for any other previous period of social development to unfold itself completely. The need for it to be reached becomes less as social consciousness. embodied this time in the socialist proletariat, becomes more involved as an active factor in the blind game of forces" ([1921] 1972: 147).

At this stage, that is, Luxemburg took the revolutionary promise of the working class for granted. Unenlightened by Michels or Weber, she held that the proletariat would rebel "against the rule of capital...long before the last consequences of economic development" ([1921] 1972: 60). It was, in fact, only the shock of the World War that led to Luxemburg's "affirmation of an historical alternative, of an outcome still to be decided and in genuine doubt" (Geras, 1976: 22). ${ }^{3}$

For Luxemburg, as for many others, the war evoked a kind of cognitive dissonance. Naïve prophecies of solidarity and selfemancipation had been strikingly disconfirmed, yet it seemed possible that future events would give them new resonance. "If the proletariat learns from this war to assert itself, to cast off its serfdom to the ruling classes, to become the master of its own destiny, the shame and misery will not have been in vain" ([1916] 1971: 334). ${ }^{26}$ Many radicals redoubled their efforts, convinced

25 Wolfgang Bonss (1984: 4) expresses this well: "Where the labor movement in the nineteenth century had, apparently, repeatedly confirmed the hypothesis that capitalism was crisis-prone and the victory of the proletariat inevitable, this empirical certainty had become increasingly fragile since the legalization of the Social Democracy..."

${ }^{26}$ The SPD had left this possibility open when they said, in July 1914, that "if the determined will for peace of the German, of the international proletariat...should not be able to prevent world war, then at least it must be the last war, it must be the Götterdämmerung of capitalism" (cited in Luxemburg. [1916] 1971: 332). 
(or hopeful) that the workers would grow weary of the war. The manifesto of the antiwar left co-signed by Pannekoek, Luxemburg. Trotsky, and others at the Zimmerwald Conference in 1915 urged a shift from war to class war - from World War to world revolution: "Proletarians! Since the outbreak of the war, you have placed your energy, your courage, your endurance at the service of the ruling classes. Now you must stand up for your ou'n cause..." (International Socialist Conference, [1915] 1961: 65; italics in the original).

For some, the Bolshevik revolution in 1917 banished all doubts. The proletariat had come to its senses; the fraternal bloodshed of the war had been a tragic aberration. Dissonant perceptions could now be restored to harmony -- a psychological shift which took place so widely, in fact, that even the ultimate glaciation of the revolution proved unproblematic for many. But for others for Luxemburg's heirs - later events proved disheartening: the failure of the Spartacist uprisings in late 1918 and early 1919; the assassination of Luxemburg and Liebknecht; and the failure of the Hungarian and Bavarian communes in mid-1919. Eugen Leviné, who had emerged as a key leader in Luxemburg's Spartacus League and who played a pivotal role in the Bavarian uprising, upheld a striking viewpoint that conveys a clear sense of the radical mood in this period. Although he had opposed the initial call for a 'Bavarian Soviet Republic' on the ground that it invited certain defeat, Leviné nevertheless assumed a position of leadership - and forfeited his life - when the Munich workers actually proclaimed a soviet republic. His reasoning was ideal-typical: "We cannot avert the catastrophe, but [we are] responsible for the state in which the workers emerge from it: as a downtrodden, disappointed herd or as high-spirited revolutionaries ready to resume the struggle." He knew the likely outcome. "Many of us," Leviné said, "will have to initiate the era of freedom with our lives."

We will tell [the workers] the truth: an honorable death and experience for the future is all we can salvage from the present situation. But this is a great contribution to our final task and is in our power to achieve. (Citations from Leviné-Meyer, 1973: 98, 98-99, 98) ${ }^{7}$

\footnotetext{
I A thousand members of the Bavarian commune were summarily executed after they were convicted on political charges by a military tribunal. One of the few to be wared was the few to be spared was the leader of the uprising, Ernst Toller, who was granted a reprieve after Max Weber spoke on his behalf (Gerth, 1964: 35-36).
}

Leviné had learned, both in Mannheim and afterwards, that the will and confidence of the working class are neither algebraic constants nor ever-rising evolutionary forces. For Leviné, and others like him, it had become clear that 'class consciousness' is a question mark -- to be accounted for, not counted upon.

History drove this lesson home. In 1921, 1923 and 1933 the German workers were beaten again and again, each time more decisively. In 1922 the Italian workers fell victim to Mussolini. In the Soviet Union, meanwhile, menacing forces were at work. The "white" counterrevolution (supported by a 14-nation military task force) produced a prolonged civil war that ultimately decimated the Russian proletariat. Ensuing misadventures led to the defeat of all supporters of "prole-tarian democracy" at the hand of an increasingly unscrupulous bureaucracy. "From 1918 to the present day, every chapter of European history could be headed: The defeat of the revolution." So wrote Anton Pannekoek in 1927, paraphrasing Marx (cited in Bricianer, 1978: 231). The dictatorship of the officials did indeed appear to be on the march.

\section{Towards Critical Theory}

It was in this context that the tradition of Weber and Levenstein was revived - not by conventional academics, but by socialists influenced by Luxemburg: Max Horkheimer, Erich Fromm, Paul Lazarsfeld, and others associated with the Frankfurt Institute for Social Research. Founded in 1923, this Institute was directed until 1931 by Carl Grünberg, an orthodox Austrian Marxist who cared little for social psychology. Something of the early flavor of the Institute emerges from a letter written to Max Eastman in 1927 by an American student, Oscar Swede, vexed by "blackboards full of mathematical juggling with blocks of $1000 \mathrm{k}$ $+400 \mathrm{w}$," all devoted to "Marx's divisions of capital's functions" (cited in Jay, 1973: 12). In 1929, however, a circle of younger faculty led by Max Horkheimer assumed day-to-day responsibility for the Institute. The results were far-reaching.

Max Horkheimer was a truly remarkable figure. From 1926-1931 -- a critical era for the workers' movement -- Horkheimer ([1934] 1978: 17-114) wrote a series of notes and aphorisms under the pseudonym "Heinrich Regius" in which he evolved a vision of a 
new kind of theory. Although faithful to Marx's view of capitalism, Horkheimer believed that Marx's labor theory of value can provide only the foundation of a social theory. Without a critique of political psychology the critique of political economy is unable to account for the most essential facts of politics: above all, the fact that the proletariat is divided. Stratified objectively, workers are also divided in their loyalties. Some fear nothing more than the loss of their jobs, while others "even today have nothing to lose but their chains." Few sentiments of real solidarity are felt - a fact which "in contemporary Germany...expresses itself through the existence of two workers' parties and the wavering of sizeable segments of the unemployed between the Communist and the National Socialist parties" (Horkheimer [1934] 1978: 61, 62-63). Workers "waver" not only in their political views but in their emotional tendencies. Many want freedom, but others are ambivalent - or prefer "order."

Though not ready, at this point, to draw sweeping conclusions about authoritarianism, Horkheimer was well aware that the impotence of the proletariat rested in part on a subjective foundation. "The capitalist process of production," he felt, "has...driven a wedge between the interest in socialism and the human qualities necessary to its implementation" ([1934] 1978: 62). Socialist "class consciousness" had been subordinated to a reformism ready to renounce class solidarity (and to "angrily dismiss Marxism") when the immediate needs of its comparatively aristocratic labor base made this expedient. The German Communist Party (KPD), meanwhile, had "exhaust[ed] itself in pointless commands [and] moral reprimands to the disobedient" ([1934] 1978: 63), unable to address or even acknowledge the feelings of resignation that had become so common among working people.

Horkheimer shared Luxemburg's view that the inner laws of capitalism lead to crisis and the collapse of the system, but he emphasized even more strongly that crisis does not necessarily yield class consciousness ([1939] 1989: 17, cited by Jacoby, 1975: 51): "Deduceable is the economic collapse, not the revolution." This was also the viewpoint urged by Henryk Grossmann, the leading economist of the Institute. In his landmark study, The Law of Accumulation and Breakdoun of the Capitalist System ([1929] 1967), Grossmann mounted a sustained argument in favor of the view that capitalist crisis and collapse are, ultimately, objectively unavoidable. At the same time, though, Grossmann took care to distance himself from the implication that he upheld "...a quietist fatalism which leaves no room for the class struggle." About this he was entirely unambiguous: "No economic system," he declared, "however weak it may ever be, collapses 'automatically'; it must be overthrown" (Grossmann, 1943. 520; cf. Trottman, 1956). The business cycle, he said, can 1943: 520; cf. Trottman, 1956). The business cyclass conflict - and the outcome of this conflict turns, in part, on psychology.

Grossmann was echoed by another Institute fellow: "Not the slightest natural necessity or automatic inevitability guarantees stion capitalism to socialism." So Herbert Marcuse argued in his major work, Reason and Revolution (1941). Though Marcuse agreed with Marxist orthodoxy $(1941: 318,319)$ Though Marcuse agre of that "the system is destined to perish by nertheless insisted fundamental laws that Marx discovered, might well be "...a long period of that the result of this conergence of "a self-conscious and barbarisn," onle can prevent organized working class on an international scale" can prevent this. Here, as elsewhere, Marcuse echoes Lux Grossmann. Either socialism or barbarism - either the free rationality' of the working class or the victory of irrationality.
"There can be no blind necessity in tendencies that terminate in a free and self-conscious society."

would be a distortion of the entire significance of Marxian theory to argue from the inexorable necessity that governs the theory to argue fromiter development of capitalism to a similar necessity in is matter of transformation to socialism. When capitalism is ne social processes no longer stand under the rule of blind social processes no nature of natural laws. This is precisely what disting
29
(1941: 318,317$)$

For Grossmann as for Marcuse, the ultimate result of capitalist crisis depends on the psychology of the proletariat.

28 Marcuse was clear about his debt to Grossmann, saying (1941: 296) that "The fundamental tendencies of Marxian economic theory are best expounded by Henryk Grossmann ..."

29 .The revolution requires the maturity of many forces, but the greatest among The them is the subjective force, namely, the revolutionary class its those who realization of freedom achieve it." (1941: 319) 
"Obviously...I know that both sides of the process, the objective and the subjective elements, mutually influence one another... My theory of collapse does not aim at the exclusion of...active intervention [by the proletariat], but rather wants to show when and under what conditions" such intervention can succeed (Grossmann, [1931] 1967: 88, cited in Marramao, 1975: 64). The basic question is not why capitalism tends to fall, but "why it has not already collapsed" (Grossmann, 1929: 289, cited in Jacoby, 1975: 36). Why, Grossmann wonders, have the epic traumas of war, exploitation, and crisis not yet provoked revolution"

To answer this question, Horkheimer ([1934] 1978) proposed a double synthesis: of Marxism and social psychology, on the one hand, and of research and theory, on the other hand. The overall goal of this double synthesis would be to fashion an "interdisciplinary materialism" oriented not only to political economy but to political psychology as well.

\section{Interdisciplinary Theory and Collective Research}

The development of this unique interdisciplinary Marxism was the objective Horkheimer had announced when he officially assumed leadership of the Institute in 1931. He had taken a major first step in this direction two years earlier when, in 1929 , he had asked Erich Fromm to carry out a political psychological study of the working-class in Westphalia, the Rhineland, and (with help from Paul Lazarsfeld) in Austria.

The spirit of this turn to psychology is well evoked by Lazarsfeld (1969: 272) in a memoir of the Viennese student movement after the Great War. "We were concerned with why our propa-ganda was unsuccessful, and wanted to conduct psychological studies to explain it. I remember a formula I created at the time: a fighting revolution requires economics (Marx); a victorious revolution requires engineers (Russia); a defeated revolution calls for psychology (Vienna)." 30 Vienna, of course, was the

\footnotetext{
30 Active in the student movement, Lazarsfeld's socialist roots were deep. He had been raised during the war by German SPD leader Rudolf Hilferding, the renowned author of Finance Capital (11910] 1981). Later he pursu ed his famous study of unemployment in Marienthal (Lazarsfeld, Jahoda, and Zeisel, [1933] 1971 ) at the suggestion of Otto Bauer, the principal leader of Austrian socia democracy
}

home of Freud and many of his leading disciples - among them the brilliant Wilhelm Reich, who would soon turn from orthodox psychoanalysis to class analysis. From 1927-1932, while organizing the German Sex-Pol movement under the banner of the German Communist Party, Reich wrote a series of pamphlets and essays on class consciousness and characterology (see Reich, 1972). In 1933, he published his two greatest works, The Mass Psychology of Fascism ([1933] 1970) and Character Analysis ([1933] 1961), and a year later he wrote a classic essay, "What is Class Consciousness?" ([1934a] 1972). Though Reich left the path of social inquiry not long afterwards, others, such as Otto Fenichel and Karen Horney, would carry the torch further.

Few of Reich's successors, however, were as imaginative as Erich Fromm. Fromm and Reich were in close communication after Reich's move to Berlin in 1930, but they later disagreed publicly on the relationship between psychoanalysis and sociology (Fromm, [1932] 1970: 113-17; Reich, [1934b] 1972: 65-74). Fromm, though better known as a psychoanalyst, started as a sociologist. In 1922, he received a doctoral degree in sociology from the University of Heidelberg for a dissertation (Fromm, [1922] 1989) supervised by Alfred Weber on a topic closely related to Max Weber's Ancient Judaism (which had appeared shortly before). Two early essays (Fromm, 1927; [1930] 1963: 3-95) delved into related topics, while a third (Fromm, 1928-29) explored the boundary between psychoanalysis and sociology.

In 1927, after matriculating from the Psychoanalytic Institute in Berlin, Fromm adopted a dually socialist and psychoanalytic outlook. According to Scholem (1977: 197), Fromm held "Trotzkyite" views and sympathized with groups to the left of the socialist and communist parties, though without joining any particular group. (Earlier he had helped to form the Freies Jüdisches Lehrhaus.) In February 1929, at the opening of the Frankfurt Psychoanalytic Institute, Fromm urged the construction of a unified social theory on the dual basis of Marxist sociology and psychoanalysis. Just months later Fromm was invited by Horkheimer to direct an Insitute study of the Weimar proletariat.

At this point, and for most of the next decade, Fromm and Horkheimer were in very close harmony. The idea of 
authoritarianism is essentially their joint contribution. So, too, was the Institute's revival of empirical social psychology. ${ }^{31}$

Since World War I little had happened in the realm of German survey research. Weber's death had deprived German social science of its leading researcher, and Levenstein's work had never been popular. Even eminent scholars who were otherwise friendly to survey research (Bernays, 1912; Herkner, 1913; Münsterberg, 1913) reviewed Levenstein's study unfavorably, refusing to give credence to data "gathered from men who are untrained in self-observation and above all who are accessible to any kind of suggestion and preconceived idea" (Münsterberg, 1913: 238). The result was that, in the words of Weber's friend and colleague, the psychologist Willy Hellpach (1922: 40-41), "Levenstein's monumental survey...has remained the only one of its kind; everything that we know about the inner life of factory workers originates from it."

Until Fromm entered the field few people accepted even the premise that the inner life of workers should be empirically studied. Fromm's investigation was hence the "first step towards the rediscovery of the proletariat as an object of empirical research" (Bonss, 1984: 15). It was also the first fruit of what became "the broadest and most advanced effort in the Weimar Republic [to build] empirical social research" (Schad, 1972: 76) an effort lasting 25 years, and culminating in both Studien über Autorität und Familie (1936) and The Authoritarian Personality (1950).

${ }^{31}$ Fromm is usually treated as a minor figure by Frankfurt School historians, most of whom accept the criticisms of Fromm leveled by Herbert Marcuse (1955). This, in my opinion, is a grave mistake, since Fromm was enormously important to the Instite for Social Research in its formative years, and since he imporans to the in Prankfurt School historians, most of whom view Horkheimer, Marcuse and Adorno as aestheticians and, culture critcs, rather than as sociological theorists (despite the fact that Horkheimer and Adorno expressly described themselves as such on many occasions; see, e.g., Horkheimer, 1952). Besides Dubiel and Bonss, few historians devote more than a few lines to the Institute's critique of authority, despite the fact that this was, for Horkheimer, manifestly the guiding theme of Institute research for well over two decades. Since this was Fromm's concern, too, his work in the 1930's has fallen into the void. "Setting this record straight would be a much appreciated work of historical research," as Rainer Funk rightly observes (Funk, 1982: 296-97).

\section{The Weimar study}

Fromm and his associates -- Hilde Rigaudias-Weiss especially ${ }^{32}-$ hoped "to gain insight into the psychic structure of manual and white-collar workers" at a vital turning point in the history of the German proletariat (Fromm, Weiss et al., 1936: 239). From 192931 - in the darkest days of the Depression - they circulated a giant questionnaire to 3,300 workers in west and central Germany. Nearly half of the 1,150 completed questionnaires were then lost during the forced flight from Germany in 1933, when, Horkheimer reports (1938), the Institut was closed for displaying "tendencies hostile to the state." A preliminary report was printed in Studien über Autorität und Familie (available in an abridged translation [IISR, 1937]) - and a fuller version, initially scheduled for publication in 1939, appeared in 1984 (Fromm, [1939] 1984).

Fromm's first summary of his Weimar research was quite substantial, forming the centerpiece of Studien über Autorität und Familie (229-469), but some of the most important data was left out, possibly for political reasons. (Similar concerns may have been involved in the non-appearance of the 1939 edition, which Columbia University had originally intended to release.) Herbert Marcuse told Wolfgang Bonss in 1979 (Bonss, 1984: 33) that fears were expressed at the time that Fromm's study would impel excessively pessimistic attitudes towards the working class.

Fromm ([1939] 1984) begins by acknowledging the dual influence of American social science and "a few attempts" by German researchers. "Here we would particularly mention A. Levenstein's social-psychological enquiry of 1912 into the workers' question - the only study which, like our own, used a questionnaire to capture social attitudes and behavior outside the work situation. ${ }^{33}$ Fromm contends, however, that neither

32 Other key collaborators included Anna Hartoch, Herta Herzog, Karl Landauer, Ernest Manheim, and Ernst Schachtel.

${ }^{33}$ In a 1971 letter to Bonss, Fromm minimized Levenstein's influence, but this denial is belied both by the direct testimony of his Weimar manuscript (about which he may have been a bit hazy, since this was, after all, an early work that he never finished) and by Autorität und Familie (232). Oberschall saw the connection on the basis of Autorität und Familie alone, saying that "The Levenstein questionnaire...exerted an indirect influence upon a line of development which has come to be one of the main areas of empirical research and theory in social psychology" (1965: 132). Bonss takes an even stronger 
Levenstein nor later researchers had shown very much theoretical acuity. ${ }^{34}$ Without the insights furnished by Marxism and psychoanalysis they were unable to fathom the larger significance of their data.

What, then, did Fromm deduce from his own data?

Not at all what he had expected. Convinced, in classic Marxist terms, that the illiberal sentiments which fueled the rise of fascism expressed the class interests of what the Bolshevik Zinoviev had called "petty bourgeois run amok," Fromm "expected a close relationship between economic status and possible types of response" ([1939] 1984: 59). This expectation was borne out only slightly. In fact, rather than confirming what Weber had called the à priori class theory, Fromm's results cast very serious doubt on this theory.

The working class, it turned out, was not quite as it had been portrayed.

Fromm's basic assumption had been that varying conditions of life give rise to "totally different personality structures with different emotional needs" (63). Specifically, Fromm had believed that "the middle class in Europe is marked by a distinct inclination to accumulate wealth, by a glorification of strength and a denigration of weakness" (62-63). Factory workers, by contrast, were imagined to feel compassion for the weak and solidarity towards one another. Evidence about party loyalties seemed to confirm this presumption. No fewer than 82 percent of Fromm's respondents belonged to the Social Democratic and Communist parties: 53 percent were Social Democrats while 29 percent were Communists. An amazing 93 percent of the trade unionists in the sample said that they attended meetings, while

position, saying (1984: 24) that Autorität und Familie shows so many signs of Levenstein's influence that Fromm's work "can in some respects be described as a second edition" of Die Arbeiterfrage. Fromm's awareness of Weber's contribution is conjectural. Rigaudias-Weiss (1932: 193ff.) avowed herself an heir to the Weberian research tradition, and Horkheimer (1952: 34) noted "...the trailblazing work of Max Weber on the sociology of religion" and remarked that the Verein's "several surveys...have contributed to the development of empirical sociological research methods." Still, Fromm says nothing about this, so his familiarity with Weber's empirical work remains uncertain.

${ }^{34}$ Besides Levenstein, Fromm cites Hendrik de Man, Siegfried Kracauer, and several others.
71 percent assumed formal organizational responsibilities; no fewer than 33 percent held union office. Nazis, meanwhile, made up an "insignificantly small" percentage of the total sample - a fact indicative of "the very slight influence which this party had among industrial workers, at least in 1930-31" (48).

Socialism and its "thought-world," in other words, were just as dominant among German workers in 1929 as they had been in Levenstein's time: "The relatively large number of members of left-wing parties in our sample [closely] corresponded to the actual political distribution of workers in urban centers at the time of the study" (49). ${ }^{35}$

The distribution of workers between parties also seemed to support Fromm's early expectations. Factory workers, making up 64 percent of the sample, were notably more likely to prefer the communist KPD to the socialist SPD, and they were also the principal supporters of the claim that the legal system is "bad, politically distorted." Workers in large factories, meanwhile, "tended to be more consistently left than workers in small enterprises" (Horkheimer, 1952: 16). White-collar workers, making up 29 percent of the total sample, were overrepresented among members of the Nazi party (comprising 36 percent of the total) and underrepresented in the KPD (making up just 14 percent of the membership). The remaining seven percent of the sample consisted of small businessmen, students, housewives, etc.

But Fromm and Horkheimer wanted more than simple census and public-opinion data. As Fromm pointed out, "it is not what someone says which is important but why he says it" (44). The Institute hence hoped to discover not only the structure of the workers' worldview but, also, their character structure. It seemed clear that the vast majority of German workers would oppose Nazism in a showdown - but would they act decisively and with unity? Would love of liberty overcome the sectarianism

${ }^{35}$ Fromm's sample was otherwise not very representative. Fewer than 9 percent of his respondents were women, just six percent were under 21 , and even fewer - three percent - were over 60 . (The average age was 31.) Most of Fromm's respondents came from urban centers situated between Frankfurt and Berlin, respondents came from urban centers situated between Frankfurt and Berlin,
while Weber's rural workers from "East of the Elbe" were left out entirely. 57 while Weber's rural workers from "East of the Elbe" were left out entirely. 57
percent were avowed atheists, 25 percent were Protestants, 11 percent Catholics and seven percent held 'other' views. 
of the left parties? To find out, Fromm "relied on the basic rule in psychological work," i.e., "that...statements about...thoughts and feelings, however truthful, cannot be taken literally but need to be interpreted" ([1939] 1984: 44). Underlying an "official" viewpoint there may be a mixed motive, or a contrary impulse.

Horkheimer says that, to test this possibility "the following method was developed: A number of questions were singled out as relevant for the respondent's political views and another as revealing his underlying personality structure." The premise was that "...'syndromes' of attitudes provide a clue to the consistency between political credo and personality" (1952: 15).

Now, 48 years after the The Authoritarian Personality, this may seem entirely commonplace. Almost no one would now deny that national, racial, and gender-linked attitudes express something basic about the political character of the people who hold these views. The same is clearly true for authority-linked views. But stating this idea in 1929 - and devising a method to test it - was a breakthrough.

Fromm focused on several kinds of attitudes: political, cultural, family, and aesthetic values; worldviews; judgements of others; and attitudes towards women and children. ${ }^{36}$ Respondents were given chances to agree or disagree with many statements about authority: in the state, in the family, in political parties, etc. Many other statements were designed to tap related values: e.g., "No, children need to be beaten in order to teach them respect" (61).

The overall results were disturbing. On the one hand, for a fair number of left-wing respondents, there was "a far-reaching accord between personality and party program. These people wanted freedom, equality, and happiness for all: they hated war and sympathized with the oppressed. Their convictions and commitment were passionate and strong" (43). This was Fromm's Revolutionärer group. Others, however, were Ambivalenter -- and still others were largely authoritarian.

\footnotetext{
${ }^{36}$ Notably absent from this list is any reference to antisemitism or ethnocentrism, two of the key categories in The Authoritarian Personality. Neither Fromm nor Horkheimer, it seems, had any real inkling at this point that German antisemitism would prove to be a profound phenomenon.
}

Although professing socialist beliefs, respondents with an authoritarian streak showed a characteristic bias in their interpretation of radical doctrine:

These people were filled with hate and anger against everyone who had money and who appeared to enjoy life. That part of the socialist platform which aimed at the overthrow of the propertied classes strongly appealed to them. On the other hand, items such as freedom and equality had not the slightest attraction for them, since they willingly obeyed every powerful authority they admired; they liked to control others... (43)

For many German workers, in other words, there was a serious "discrepancy" between political beliefs and character. Although Fromm and Horkheimer had anticipated this possibility they were startled by its dimensions. Careful sifting of the data yielded the conclusion that only 15 percent of the KPD and SPD members were genuinely radical personalities - while 25 percent were either potentially or primarily authoritarian. "They conjectured that this would mean that little resistance could be expected, fears that were heightened by the Nazi victories in the elections of the first depression year, in September 1930" (Katz, 1982: 86). The unrepresentativeness of the sample left open the hope that this problem might not be as pervasive or fundamental as it seemed, but the consistency of the data suggested otherwise. "The replies to questions concerning the most disparate departments of life proved to be so true to type that when half the answers were known, the other half was predictable" (Fromm, 1936c: 916).

Some workers showed a positive affinity for the Nazi rhetoric of ressentiment. Many more revealed "a frightening lack of a will to resist" ([1939] 1984: 43). Franz Neumann (1944) tells of the "complete failure" of the socialist parties and unions "to appreciate the real character of National Socialism." On May 1, 1933, many socialists joined a grotesque Nazi "salute to labor," hoping to dissuade the new rulers from taking ruthless steps against organized labor. The next day stormtroopers seized every union headquarters. "It took exactly 30 minutes," Neumann recalls (1944: 414), "for the huge trade-union structure to collapse. There was no resistance; no general strike, not even a demonstration of any significance. What further proof is needed that the German trade-union organizations had outlived their usefulness." They had become machines without 
enthusiasm or flexibility. They no longer believed in themselves." ${ }^{37}$

Horkheimer always denied that this failure was predestined. "The idea that in the early thirties the united workers, along with the intelligentsia, could bar the way to National Socialism was not mere wishful thinking" (Horkheimer, 1972, preface: v). This seems clearly true. Between them, the SPD and KPD enjoyed substantially more electoral support than the Nazi Party did, even in 1932. Both were commanding presences in German politics, with militias, massive trade-union backing, and millions of followers. Yet when zero hour came, they proved incapable of unity.

Fromm and Horkheimer believed that they had unearthed a partial explanation for this failure. The German proletariat, it turned out, was neither uniformly radical nor anti-authoritarian. Contrary to orthodox Marxist precepts, "the discrepancy of the personality structures between the classes is, empirically, not as clear as one might assume" (Fromm, [1939] 1984: 63). There was, in fact, "a rift between the economic and psychic development of the classes... Our material clearly shows that many workers exhibit personality traits which...do not accord with their socialist views." Especially notable, they felt, is the fact that some workers identify with authoritarian values. "The authoritarian attitude affirms, seeks out and enjoys the subjugation of men under higher external power, whether this power is the state or a leader, natural law, the past or God. The strong and powerul are simply admired and loved for these qualities, the weak and helpless hated and despised..."

Sacrifice and duty, and not pleasure in life and happiness, are the guiding aims of the authoritarian attitude ([1939] 1984: 209$10)$.
Even when impulses of this kind go "against all common sense" they can still be compelling because of their "close ties with emotional needs" ([1939] 1984: 62).

This, in a nutshell, was the Institute's discovery. The a priori class theory repudiated by Max Weber had proven barren. Rather than abandoning class-theory, however, Fromm and Horkheimer sought to place it on a sound empirical and historical foundation. "Consciousness" could no longer be "imputed" to classes, as Lukács had maintained; it had to be studied. And, upon inspection, it proved to be deeply contradictory.

\footnotetext{
37 Neumann, prior to joining the Institut in 1937, was himself a leading Social Democrat, something for which he was later remorseful. As he wrote to a friend in 1954, I believe in collective guilt... I saw with my own eyes how deceitful the German Social Democratic Party was in the months from July 1932 to May 1933 (and not only then) and I said nothing. I saw how cowardly the union bosse were -- and I continued serving them. I saw how twofaced th - and I remained silent" (cited in Söllner, 1981-82: 171-72).
} 


\section{REFERENCES}

ABBREVIATIONS:

Archiv Max Weber, Werner Sombart and Edgar Jaffé. Archiv für Sozialwissenschaft und Sozialpolitik. Tübingen: Mohr-Siebeck.

AuF Max Horkheimer, Ed. 1936. Schriften des Instituts für Sozialforschung, Vol. 5: Studien über Autorität und Familie: Forschungsberichte aus dem Institut für Sozialforschung. Paris: Librairie Félix Alcan.

EP Paul Edwards, Ed. 1967. Encyclopedia of Philosophy. New York: Macmillan and The Free Press.

ESS Edwin R. A. Seligman and Alvin Johnson, Eds. 19301935. Encyclopaedia of the Social Sciences. New York: Macmillan.

FMW Hans H. Gerth and C. Wright Mills, Eds. 1946. From Max Weber: Essays in Sociology. New York: Oxford University Press.

GA Max Weber. 1924. Gesammelte Aufsätze zur Soziologie Aufsätze und Sozialpolitik. Tübingen: J.C.B. Mohr.

MCWS Claus D. Kernig, Ed. 1972. Marxism, Communism, and Western Society: A Comparative Encyclopedia. New York: Herder \& Herder.

MECW Karl Marx \& Frederick Engels, 1975-. Collected Works, Vols. 1-47. London: Lawrence \& Wishart.

MWG Horst Baier, M. Rainer Lepsius, et al., Eds. 1984-. Max Weber Gesamtausgabe. Tübingen: J. C. B. Mohr (Paul Siebeck). Abteilung 1 (Schriften und Reden), 8 vols. in 10 books. Abteilung 2 (Briefe), 2 vols.

MW:S W. G. Runciman, Ed. 1978. Max Weber: Selections. Cambridge: Cambridge University Press.

Schriften Verein für Sozialpolitik. Schriften. Leipzig: Duncker \& Humblot.

ZfS Max Horkheimer, Ed. Zeitschrift für Sozialforschung. Paris: Librairie Félix Alcan.

Abbé, Ernst. 1906. Gesammelte Schriften, Vol. 3: Sozialpolitische Schriften. Jena. G. Fischer Verlag.

Adorno, T. W. 1950. "Democratic Leadership and Mass

Manipulation," in Alvin Gouldner, Ed. Studies in Leadership.

New York: Harper \& Brothers.

. 1967. "Sociology and Psychology," in New Left Review, 46
Adorno, T. W. and R. N. Sanford, Else Frenkel-Brunswik, and Daniel J. Levinson. 1950. The Authoritarian Personality. New York: Harper \& Brothers.

Ayçoberry, Pierre. 1981. The Nazi Question: An Essay on the Interpretation of National Socialism (1922-1975), translated by Robert Hurley. New York: Pantheon.

Benjamin, Jessica. 1988. The Bonds of Love: Psychoanalysis, Feminism, and the Problem of Domination. New York: Pantheon.

Bernart, Maura de. 1986. "Le ricerche di Max Weber sui lavatori agricoli, 1892-1899: Opere 'minori'," in Sociologia, 20.

Bernays, Marie. 1911. "Psychophysik der Textilarbeit," in Archiv, 32.

1912. Review of Levenstein, 1912, in Archiv, 35.

Boese, Franz. 1939. Geschichte des Vereins für Sozialpolitik 1872-1932. Im Auftrage des Liquidationsausschusses verfast vom Schriftfïhrer. (Schriften, Bd. 188). Berlin: Duncker \& Humblot.

Bonss, Wolfgang. 1984. "Preface" to Fromm (1939) 1984.

Bricianer, Serge. 1978. Pannekoek and Workers' Councils. St. Louis: Telos Press.

Briefs, Goetz. 1937. The Proletariat: A Challenge to Western Civilization. London and New York: McGraw-Hill.

Briggs, Asa. 1972. "Popular Movements," in MCWS, Vol. 6.

Cabet, Étienne. 1840. Voyage en Icarie. Paris: Bureau de Populaire.

Dubiel, Helmut. 1985. Theory and Politics. Cambridge MA and London: MIT Press.

Eden, Robert. 1983. Political Leadership and Nihilism: A Study of Weber and Nietzsche. Tampa: University Presses of Florida.

Fetscher, Iring. 1972. "Socialism," in MCWS, Vol. 7.

Foster, John. 1974. Class Struggle and the Industrial Revolution. London: Weidenfeld and Nicholson.

Fromm, Erich. (1922) 1989. Das jüdische Gesetz. Zur Soziologie des Diasporas-Judentums. Weinheim and Basel: Beltz Verlag. Edited by Rainer Funk and Bernd Sahler. First published as a doctoral dissertation at the University of Heidelberg.

1927. "Der Sabbath," in Imago: Zeitschrift fïr Anwendung der Psychoanalyse auf Natur- und Geisteswissenschaften, $13 . \quad$ Vienna: Internationaler Psychoanalytischer Verlag. 
1928/29. "Psychoanalyse und Soziologie" in Zeitschrift für Psychoanalytische Pädogogik, 3. Vienna.

(1930) 1963. "Die Entwicklung des Christusdogmas," in Imago, Vol. 16; also available in Fromm, 1963, pp. 3-95.

(1932) 1970b. "The Method and Function of an Analytic Social Psychology," in Fromm, 1970b, pp. 113-117. From ZfS, 1.

1936a. "Sozialpsychologischer Teil," in $A u F$.

1936b. "Die Arbeiter- und Angestellten-Erhebung," in

AuF. Available in English; see IISR, 1937.

1936c. "Second Section: Empirical Approaches," in $A u F$.

1937. "Zum Gefühl der Ohnmacht," in ZfS, 6.

(1939) 1984. The Working Class in Weimar Germany: A

Psychological and Sociological Study. Cambridge, MA: Harvard University Press.

1941. Escape From Freedom. New York: Farrar and Rinehart.

. 1947. Man For Himself. New York: Rinehart and Company.

1955. The Sane Society. New York: Rinehart and Winston.

1963. The Dogma of Christ and Other Essays. New York:

Holt, Rinehart and Winston.

1970a. Social Character in a Mexican Village. Englewood Cliffs, NJ: Prentice-Hall.

1970b. The Crisis in Psychoanalysis: Essays on Freud, Marx, and Social Psychology. New York: Holt, Rinehart and Winston.

1973. The Anatomy of Human Destructiveness. New York: Holt, Rinehart and Winston.

Fromm, Erich, Hilde Weiss, et al. 1936d. "Die Einzeln Erhebungen," in $A u F$.

Funk, Rainer. 1982. Erich Fromm. New York: Continuum.

Geiger, Theodor. 1930. "Panik im Mittelstand." Pp. 637-654 in Die Arbeit, 7.

1932. Die soziale Schichtung des deutschen Volkes: Soziographischer Versuch auf statistischer Grundlage. Stuttgart: Ferdinand Enke Verlag.

Geras, Norman. 1976. The Legacy of Rosa Luxemburg. London: New Left Books.

Gerth, Hans H. (1964) 1984. "Max Weber's Political Morality," in Ronald M. Glassman and Vatro Murvar, Eds. Max Weber's Political Sociology. Westport: Greenwood.

Göhre, Paul. (1891) 1895. Three Months in a Workshop: A Practical Study. London: Swan Sonnenschein. Reprinted in
New York in 1972 by Arno Press. First published as Drei Monate Fabrikarbeiter. Leipzig: Grunow.

Goldhagen, Daniel Jonah. 1996. Hitler's Willing Executioners: Ordinary Germans and the Holocaust. New York: Alfred A. Knopf.

Goldhagen, Erich. 1978. "Obsession and Realpolitik in the 'Final Solution'." Pp. 1-16 in Patterns of Prejudice, 12 (1).

1979. "The Mind and Spirit of East European Jewry During the Holocaust," The Beiner-Citrin Memorial Lecture. Cambridge: Harvard College Library.

Gorges, Irmela. 1980. Sozialforschung in Deutschland 18721914. Gesellschaftliche Einflüsse auf Themen- und Methodenwahl des Vereins für Sozialpolitik. Königstein: Verlag Anton Hain.

Grossmann, Henryk. (1929) 1967. Das Akkumulations- und Zusammenbruchsgesetz des kapitalistischen Systems. Frankfurt a.M.: Verlag Neue Kritik.

(1931) 1969. Letter to Paul Mattick, June 21, 1931; appended to $\mathrm{H}$. Grossman, Marx, die klassische Nationalökonomie und das Problem der Dynamik. Frankfurt a.M.: Europaische Verlaganstalt.

1943. "The Evolutionist Revolt against Classical Economics," in The Journal of Political Economy, 3.

Hamilton, Richard F. Who Voted for Hitler? Princeton NJ: Princeton University Press.

Held, David. 1980. Introduction to Critical Theory: Horkheimer to Habermas. Berkeley and Los Angeles: University of California Press.

Hellpach, Willy Hugo. 1922. Gruppenfabrikation. Berlin: Springer.

Hennis, Wilhelm. 1988. Max Weber: Essays in Reconstruction. London: Unwin Hyman.

Herkner, Heinrich. 1912. "Problem der Arbeiterpsychologie unter besonderer Rücksichtnahme auf Methode und Ergebnisse der Vereinserhebungen." Pp. 117f. in Verhandlungen des Vereins für Sozialpolitik in Nürnberg 1911. (Schriften, Bd. 137, Teil 4). Leipzig \& Munich: Duncker \& Humblot.

1913. Review of Levenstein, 1912, in Jahrbücher für Nationalökonomie und Statistik, 99. Stuttgart: G. Fischer Verlag.

Hilferding, Rudolf. (1910) 1981. Finance Capital. London and Boston: Routledge Kegan Paul. 
Honigsheim, Paul. 1946. "Max Weber as Rural Sociologist," in Rural Sociology. 11.

1949. "Max Weber as Historian of Agriculture and Rural Life," in Agricultural History, 23.

Horkheimer, Max. 1931. "Die gegenwärtige Lage der Sozialphilosophie unde die Aufgaben eines Instituts für Sozialforschung," in Frankfurter Universitäts-reden. Frankfurt a.m.

(1934) 1978. Dawn and Decline. New York: Seabury.

(1936a) 1972. "Authority and the Family," in Critical Theory: Selected Essays. New York: Seabury. First published in $A u F$.

(1936b) 1993. "Egoism and Freedom Movements." Pp. 49-110 in Max Horkheimer, Between Philosophy and Social Science: Selected Early Writings, translated by G. F. Hunter et al. London \& Cambridge MA: MIT Press. First published in $Z f S, 5$.

. 1938. International Institute of Social Research: A Report on its History, Aims, and Activities 1933-1938. New York: IISR.

. (1939) 1989. "The Jews in Europe," in Kellner and Bronner, 1989. First published as "Die Juden und Europa" in Studies in Philosophy and Social Science/Zeitschrift für Sozialforschung, 8. Paris: Librairie Félix Alcan.

(1942) 1973. "The Authoritarian State," in Telos 15.

1952. Survey of the Social Sciences in Western Germany.

Washington, D.C.: Library of Congress.

1972a. "Preface," in Horkheimer, 1972b.

1972b. Critical Theory; Selected Essays. New York: Seabury.

IISR. 1937. Authority and the Family. (This is a translation of Fromm, 1936b). New York: International Institute of Social Research and the Columbia University Department of Social Science.

International Socialist Conference. (1915) 1961. "The Zimmerwald Manifesto," in Helmut Gruber, Ed. International Communism in the Era of Lenin: A Documentary History. Greenwich, CN: Fawcett.

Jacoby, Russell. 1975. "The Politics of the Crisis Theory: Towards the Critique of Automatic Marxism II," in Telos 23.

Jay, Martin. 1973. The Dialectical Imagination. Boston: Little, Brown and Company.

Käsler, Dirk. 1988. Max Weber: An Introduction to His Life and World. Chicago: The University of Chicago Press.
Katz, Barry. 1982. Herbert Marcuse and the Art of Liberation. London: Verso.

Kele, Max. 1972. Nazis and Workers: National Socialist Appeals to German Labor, 1919-1933. Chapel Hill: University of North Carolina Press.

Kellner, Douglas and Stephen Eric Bronner, Eds. 1989. Critical Theory and Society: A Reader. New York: Routledge.

Kelly, Alfred. 1987. "Introduction," in A. Kelly, Ed. 1987. The German Worker. Working-Class Autobiographies from the Age of Industrialization. Berkeley, Los Angeles, and London: University of California Press.

Kern, Horst. 1982. Empirische Sozialforschung: Ursprung, Ansatze, Entwicklungslinien. Munich: Beck.

Kernig, Claus D. 1972 "Proletariat," in MCWS, Vol. 5.

Kollontai, Alexandra. (1915) 1977. "Why was the German Proletariat Silent during the July Days?," in A. Kollontai, Selected Writings. New York and London: W. W. Norton. First published in Kommunist (1-2), September 1915.

Lazarsfeld, Paul. 1965. "Preface," in Anthony Oberschall. Empirical Social Research in Germany, 1848-1914. Paris and the Hague: Mouton.

. 1969. "An Episode in the History of Social Research: A Memoir," in Donald Fleming and Bernard Bailyn, Eds. The Intellectual Migration: Europe and America, 1930-1960. Cambridge, MA: Harvard University Press.

Lazarsfeld, Paul, Marie Jahoda, and Hans Zeisel. (1933) 1971. Marienthal: The Sociography of an Unemployed Community. Chicago: Aldine, Atherton. First published as Die Arbeitslosen von Marienthal.

Lazarsfeld, Paul and Anthony Oberschall. 1965. "Max Weber and Empirical Social Research," in American Sociological Review, 30.

Levenstein, Adolf. 1909a. Aus der Tiefe. Berlin: Morgen-Verlag. 1909b. Arbeiterphilosophen und Dichter. Berlin: MorgenVerlag.

1912. Die Arbeitefrage. Mit besonderer Berücksichtigung der sozialpsychologischen Seite des modernen Grossbetriebes und der psycho-physischen Einwirkung auf die Arbeiter. Munich: Verlag Ernst Reinhardt.

Leviné-Meyer, Rosa. 1973. Leviné: The Life of a Revolutionary. Glasgow: Saxon House.

Lipset, Seymour Martin. 1959. "Der 'Faschismus', die Linke, die Rechte unde die Mitte." Pp. 401-404 in Kölner Zeitschrift für Soziologie und Sozialpsychologie, 11. 
Löwenthal, Leo and Norbert Guterman. 1949. Prophets of Deceit. New York: Harper \& Brothers.

Luxemburg, Rosa. (1913) 1951. The Accumulation of Capital. London: Routledge and Kegan Paul.

(1916) 1971. "The Crisis in German Social Democracy," in Dick Howard, Ed. Selected Political Writings: Rosa Luxemburg. New York and London: Monthly Review Press. (1916) 1951. Ausgewählte Reden und Schriften, Vol 2. Berlin: Dietz.

. (1921) 1972. "The Accumulation of Capital - An AntiCritique," in Rosa Luxemburg and Nikolai Bukharin, Imperialism and the Accumulation of Capital. London and New York: Monthly Review Press.

Mannhardt, Wilhelm. 1865. Roggenwolf und Roggenhund: Beitrag zur germanischen sittenkunde. Danzig: C. Ziemssen.

Marcuse, Herbert. (1934) 1988. "The Struggle Against Liberalism in Totalitarianism," in Marcuse, 1988 . Reprinted from ZfS.

(1936) 1983. "A Study on Authority," in Marcuse, 1972. First published in $A u F$.

(1937) 1988. "The Affirmative Character of Culture," in Marcuse, 1988. Reprinted from $Z f S$.

1941. Reason and Revolution. New York: Oxford

University Press.

1955. Eros and Civilization. Boston: Beacon.

1983. From Luther to Popper. London: Verso.

1988. Negations. London: Free Association.

Marramao, Giacomo. 1975. "Political Economy and Critical Theory," in Telos 24.

Mason, Tim. [1977] 1993. Social Policy in the Third Reich: The Working Class and the 'National Community', edited by Jane Caplan and translated by John Broadwin. Oxford and Providence, RI: Berg, 1993.

Matte, Wilhelm. 1921. "Die Bayrischen Bauernräte," in München Volker Stiftung, 144.

Marx, Karl. (1867) 1976. Capital, Vol. 1. New York: Vintage. (1880) 1989. "Workers' Questionnaire." Pp. 328-334 in $M E C W$, Vol. 24, edited by Marina Doroshenko, Valentina Ostrikova, and Valentina Smirnova. New York: International Publishers.

Marx, Karl and Friedrich Engels. (1848) 1994. "The Manifesto of the Communist Party." Pp. 105-185 in Hal Draper, The Adventures of the Communist Manifesto. Berkeley, CA: Center for Socialist History.
Michels, Robert. (1911) 1968. Political Parties. New York and London: The Free Press.

Münsterberg, Hugo. 1913. Psychology and Industrial Efficiency. Boston and New York: Houghton Mifflin. Reprinted in New York in 1973 by Arno Press.

Munters, Q. J. 1972. "Max Weber as Rural Sociologist," in Sociologica Ruralis, 12.

Neumann, Franz. 1944. Behemoth: The Structure and Practice of National Socialism. Second edition. New York and Toronto: Oxford University Press.

Oberländer, Erwin. 1972. "Communism," in MCWS, Vol. 2.

Oberschall, Anthony. 1965. Empirical Social Research in Germany, 1848-1914. Paris and the Hague: Mouton.

Peukert, Detlev J. K. [1989] 1994. "The Genesis of the "Final Solution" from the Spirit of Science." Pp. 274-299 in Nazism and German Society, 1933-1945, edited by David F. Crew. London and New York: Routledge. Excerpted from Detlev Peukert, Max Webers Diagnose der Moderne. Götttingen: Vandenhoek \& Ruprecht.

Piechowski, Paul. 1927. Proletarischer Glaube. Berlin: FurcheVerlag.

Popp, Adelheid. 1912. The Autobiography of a Working Woman. London. First published in Munich in 1909 as Die Jugendgeschichte einer Arbeiterin, with an introduction by August Bebel; reprinted by Dietz Verlag in Berlin in 1983, edited by Hans J. Schütz.

Querton, Louis. 1905. L'augmentation du rendement de la machine humaine. Brussels: Misch and Thron.

Rabinbach, Anson. 1992. The Human Motor: Energy, Fatigue, and the Origins of Modernity. Berkeley \& Los Angeles: University of California Press.

Rade, Max. 1898. "Die religiöse-sittliche Gedankenwelt unserer Industrie-arbeiter," in Verhandlungen des Neunten Evangelisch-Sozialen Kongresses.

Raehlmann, Irene. 1988. Interdisziplinäre Arbeitswissenschaft in der Weimarer Republik. Eine wissenschafts- soziologische Analyse. Opladen: Westdeutscher Verlag.

Reich, Wilhelm. (1933) 1970. The Mass Psychology of Fascism. New York: Farrar Straus Giroux. First published as Massenpsychologie des Faschismus in Copenhagen by Sexpol Verlag.

(1933) 1961. Character Analysis. New York: Farrar Straus Giroux. First published as Charakter-Analyse in Copenhagen by Sexpol Verlag. 
1972.

(1934a) 1972. "What is Class Consciousness?" in Reich, . (1934b) 1972. "Dialectical Materialism and Psychoanalysis," in Reich, 1972.

1972. Sex-Pol: Essays, 1929-1934. New York: Random House.

Riesebrodt, Martin. 1984. Max Webers Gesamtausgabe, Vol. 3: Max Weber, Die Lage der Landarbeiter im ostelbischen Deutschland 1892. Tübingen: J.C.B. Mohr (Paul Siebeck).

Rigaudias-Weiss, Hilde. 1932. Review of Jürgen and Marguerite Kuczynski, Die Lage der deutschen Industriearbeiter, in ZfS, 1.

1936a. Les Enquêtes Ouvrières en France entre 1830 et 1848. Paris: Librairie Félix Alcan.

1936b. "Die Enquête Ouvrière von Karl Marx," in ZfS, 5.

Ritter, Gerhard. 1948. Europa und die deutsche Frage. Munich: München Verlag.

Roiser, Martin and Carla Willig. 1995. "The Hidden History of Authoritarianism." Pp. $77-97$ in History of the Human Sciences, 8 (4).

Rosenberg, Arthur. 1934. Der Faschismus als Massen-bewegung.

Rotteck, Karl von and Karl Welcker, Eds. 1846. Das Staatslexikon: Encyklopadie der sammtlichen staatswissenschaften für alle stande. Altona: J.F. Hammerich. (12 vols., 1845-1848)

Rubel, Maximilien. 1957. Karl Marx; essai de biographie intellectuelle. Paris: Librairie M. Riviere et Cie.

Scaff, Lawrence. 1989. Fleeing the Iron Cage: Culture, Politics, and Modernity in the Thought of Max Weber. Berkeley, Los Angeles, and London: The University of California Press.

Schad, Susanna Petra. 1972. Empirical Social Research in Weimar Germany. Paris and the Hague: Mouton.

Schmidt, Gert. 1976. "Max Weber and Modern Industrial Sociology: A Comment on Some Recent Anglo-Saxon Interpretations." Pp. 47-73 in Sociological Analysis and Theory, 6 (1).

Schnapper-Arndt, Gottlieb. 1881. “A Social Statistical Investigation of Small Peasantry, Cottage Industry and Folklife," in Schriften.

. 1888. Methodologie Sozialer Enqueten. Frankfurt a.M.

Scholem, Gershom. 1977. Von Berlin nach Jerusalem. Frankfurt a.M.: Suhrkamp.

Schweitzer, Arthur. 1970. Die Nazifierung des Mittelstandes. Stuttgart.
Smith, David N. 1974. Who Rules the Universities? An Essay in Class Analysis. New York \& London: Monthly Review Press. 1992. "The Beloved Dictator: Adorno, Horkheimer, and the Critique of Domination." Pp. 195-230 in Current Perspectives in Social Theory, 11.

1994. "Ambiguous Legacy: Fascism and the Social Sciences." Pp. 456-467 in Sociological Inquiry, 64:4 (Fall, 1994).

- 1995. "Uncivil Society: 'Race' and Murder in Nazi Germany." Pp. 123-126 in Patterns of Prejudice, 29:3 (September).

1996. "The Social Construction of Enemies: Jews and the Representation of Evil." Pp. 203-240 in Sociological Theory, 14:3 (November).

1998. "The Psychocultural Roots of Genocide: Legitimacy and Crisis in Rwanda." The American Psychologist (53:7, July 1998), forthcoming.

Söllner, Alfons. 1981-82. "Franz Neumann," in Telos 50.

Sombart, Werner. 1906. Das Proletariat: Bilder und Studien. Vol. 1 of the series Die Gesellschaft: Sammlung Sozialpsychologischer Monographien, edited by Martin Buber. Frankfurt a. M.: Literarische Anstalt, Rütten \& Loening.

Stachura, Peter D. 1983. "The NSDAP and the German Working Class, 1925-1933." Pp. 131-153 in Towards the Holocaust, edited by Michael N. Dobkowski and Isidor Wallimann. Westport CT and London: Greenwood Press.

Stein, Lorenz von. 1842. Der sozialismus und Communismus das heutizen Frankreichs. Leipzig: O. Wigand.

Tar, Zoltan. 1977. The Frankfurt School: The Critical Theories of Max Horkheimer and Theodor W. Adorno. New York: Wiley.

Tribe, Keith. 1983. "Prussian Agriculture - German Politics: Max Weber, 1892-1897," in Economy and Society, 12.

Trottmann, Martin. 1956. Zur Interpretation und Kritik der Zusammenbruchstheorie von Henryk Grossmann. Zurich: Polygraphischer Verlag.

Vierkandt, Alfred. 1935. "Wilhelm Max Wundt," in ESS, Vol. 15.

Weber, Alfred, Marie Bernays et al. 1909-1911. "Unter-suchungen über Auslese und Anpassung (Berufswahl und Berufsschicksal) der Arbeiter in der Grossindustrie," in Schriften, 132-135. Leipzig: Duncker and Humblot.

Weber, Marianne. (1926) 1975. Max Weber: A Biography. New York and London: Wiley Interscience. 
Weber, Max. 1892. "Die Verhältnisse der Landarbeiter im ostelbischen Deutschland," in Schriften, $55 . \quad$ Leipzig: Duncker and Humblot. Also published as:

. [1892] 1984a \& 1984b. Die Lage der Landarbeiter im ostelbischen Deutschland, edited by Martin Riesebrodt. $M W G$, Abt. 1, Bd. 3, Hbd. 1 \& 2. Tübingen: J. C. B. Mohr (Paul Siebeck).

(1892-1899) 1993. Landarbeitschaftsfrage, Nationalstaat und Volkswirtschaftspolitik, in $M W G$ Abt. 1, Bd. 4, Hbd. 2.

1893. "Die Erhebungen des Evangelisch-Sozialen Kongresses über die Verhältnisse der Landarbeiter Deutschlands," in Christliche Welt. Reprinted in MWG (18921899) 1993.

1904-05. "Die protestantische Ethik und der 'Geist' des Kapitalismus," in Archiv, 20.

(1906) 1946. "The Protestant Sects and the Spirit of Capitalism," in FMW. First published as "Kirchen' und 'Sekten"' in the Frankfurter Zeitung.

- 1908. "Methodologische Einleitung für die Erhebungen des Vereins für Sozialpolitik über Auslese und Anpassung (Berufswahl und Berufsschicksal) der Arbeiterschaft der geschlossenen Grossindustrie," in GA First published (under a slightly different title) by Pierersche Hofbuchdruckerei Stephan Greibel \& Co.

(1908-09) 1924. "Zur Psychophysik der industriellen Arbeit," in GA. First published in Archiv, 28.

. (1908-09) 1978. "Industrial Psychology," in MW:S. This is a translated excerpt from (1908/09) 1924.

. (1908-09) 1995. Zur Psychophysik der industriellen Arbeit, edited by Wolfgang J. Mommsen with Sabine Frommer. $M W G$, Abt. 1, Bd. 11. Tübingen: J. C. B. Mohr (Paul Siebeck). 1909. "Zur Methodik Sozialpsychologischer Enqueten und ihrer Bearbeitung," in Archiv, 29.

1912. "Probleme der Arbeiterpsychologie unter besonderer Rücksichtnahme auf Methode und Ergebnisse der Vereinserhebungen," in Schriften, 138. Leipzig: Duncker and Humblot.

(1916) 1946. "The Social Psychology of the World Religions," in FMW. First published as "Die Wirtschaftsethik der Weltreligionen: Religionsoziologische Skizzen. Einleitung," in Archiv, 41.

. (1916) 1964. The Religion of China. Glencoe, IL: The Free Press. First published as "Die Wirtschaftsethik der Weltreligionen: Der Konfuzianismus" in Archiv, 41.
(1916-17) 1967. The Religion of India. Glencoe, IL: The Free Press. First published as "Die Wirtschaftsethik der Weltreligionen: Hinduismus und Buddhismus," in Archiv, 41,42 .

(1917-18) 1952. Ancient Judaism. Glencoe, IL: The Free Press. First published as "Die Wirtschaftsethik der Weltreligionen: antike Judentum" in Archiv, 44, 46.

. (1918) 1967. Socialism. Durban, South Africa: University of Natal, Institute for Social Research, Occasional Paper No. 11. First published in Vienna by Kommissionsverlag Dr. Viktor Pimmer.

(1919) 1946. "Politics as a Vocation," in FMW. First published as "Politik als Beruf" in Max Weber, 1919. Geistige Arbeit als Beruf: Vier Vortrage vor dem Freistudentischen Bund. Munich and Leipzig: Duncker and Humblot.

(1920) 1958. The Protestant Ethic and the Spirit of Capitalism. New York: Scribners. Translated from the revised second edition of "Die protestantische Ethik und der Geist des Kapitalismus" in Max Weber, 1920. Gesammelte Aufsätze zur Religionssoziologie. Tübingen: Mohr-Siebeck.

(1922) 1978. Economy and Society: An Outline of Interpretive Sociology. Berkeley, Los Angeles and London: University of California Press.

1924. Gesammelte Aufsätze zur Soziologie Aufsätze und Sozialpolitik. Tübingen: J.C.B. Mohr.

Weber, Max, Ed. 1899. Einzeldarstellungen nach den Erhebungen des Evangelisch-Sozialen Kongresses. Tübingen: H. Laupp.

Wiggershaus, Rolf. 1994. The Frankfurt School, translated by Michael Robertson. Cambridge, MA: The MIT Press. First published in Germany in 1986. 